\title{
KACHLE S BISKUPSKÝM MOTIVEM Z UHERSKÉHO HRADIŠTĚ A JEJICH VAZBA K JANU FILIPCOVI ${ }^{1}$
}

\section{DANA MENOUŠKOVÁ}

Abstrakt: Tématem práce je ikonograficky ojedinělý, historicky cenný, bohužel jen zčásti zachovaný reliéf kachle z konce 15. až počátku 16. století pocházející ze staršího, nálezově velmi bohatého predstihového výzkumu v Uherském Hradišti, Otakarově ulici. Nález je možné spojit s činností hrnčiřských dílen, které na lokalitě působily. Torzálně zachovaný motiv s mitrou, berlou a nápisovou páskou odkazuje k osobě velkovaradínského biskupa, olomouckého administrátora a v neposledni řadé i významného diplomata Jana Filipce. Ten se mimo jiné zasloužil o založeni františkánského kláštera v Uherském Hradišti, v jehož prostoru našel po ukončeni aktivni kariéry i misto svého posledního odpočinku. Text tak reflektuje i tyto Filipcovy vazby k regionu a zamýšli se nad osobou možného objednavatele kachlového reliéfu. Ikonografický rozbor motivu kachle odkazujici k Janu Filipcovi je podpořen epigrafickou analýzou textu nápisové pásky z reliéfu kachle.

Klićová slova: komorové kachle - reliéf s biskupským motivem - Uherské Hradiště - Jan Filipec - františkánský klášter-přelom 15. a 16. století.

\section{Tiles with an episcopal motif from Uherské Hradiště and their link to Jan Filipec ${ }^{2}$}

Abstract: This paper examines an iconographically unique and historically valuable relief on a tile from the late 15th century or the early 16th century which is unfortunately only partially preserved. The relief was part of an earlier find of a rich series from research in Uherské Hradišté, Otakarova Street that can be linked to the activities of pottery workshops on this site. The fragment of a motif with a mitre, a crosier and a band with inscription refers to Jan Filipec, a bishop in Oradea (Romania), an Olomouc administrator and also a prominent diplomat. Among other things, he is credited with the establishment of a Franciscan monastery in Uherské Hradiště where he spent his last years and which also became his final resting place. The article conveys Filipec's ties with the region and discusses the possible commissioner of the relief. The iconographic analysis of the motif referring to Jan Filipec is supported by the epigraphic analysis of the text on the inscription band in the tile relief.

Key words: chamber tiles - relief with episcopal motif - Uherské Hradiště - Jan Filipec - Franciscan monastery - 15th/16th century.

\section{Nálezové okolnosti kusů}

Dva fragmenty komorového kachle s poloválcovou komorou a s motivem biskupské mitry, berly a nápisové pásky s textem v gotické minuskule byly získány již v roce 1979 při předstihovém archeologickém výzkumu na místě demolovaných domů přiléhajících k městskému opevnění na ulici Otakarově (obr. 1) v Uherském Hradišti. ${ }^{3}$ Tato poloha byla původně součástí předměstského sídliště a do prostoru obehnaného městským opevněním byla zahrnuta až v polovině 16 . století. Již před výstavbou kamenných hradeb se zde usadili hrnčíři - z písemných pramenů je doložen nejstarší název ulice „Hrnčířská“ (pro 15.-17. století: Čoupek 1984; Fišer 1921, 88). Př́ítomnost

\footnotetext{
1 Následující text je dedikován akademickému sochaři a přednímu českému medailérovi Michalu Vitanovskému, znalci v oblasti kachlové heraldiky a technologie $\mathrm{k}$ jeho životnímu jubileu. Jemu jsem také zavázána za inspirativní podněty a náměty, jimiž mne nejen při studiu tohoto motivu obohatil. Homo doctus in se semper divitias habet.

2 The article is dedicated to the academic sculptor and a leading Czech medal-maker Michal Vitanovský, a specialist in the area of tile heraldry and technology, on the occasion of his jubilee. I am indebted to him for inspirational stimuli and subjects not only in the study of this motif. Homo doctus in se semper divitias habet.

3 Za poněkud opožděným publikováním, byt' jen dílčích částí materiálu z výzkumu v Uherském Hradišti, Otakarově ulici, stojí více faktorů. Jedním z nich je rozsah výzkumu, v jehož důsledku chybí kompletní nálezová zpráva. Vycházet lze především ze záznamů v terénních denících (autorem je Rudolf Procházka). Vedle toho byl v roce 1997 archeologický depozitář Slováckého muzea, včetně materiálu z Otakarovy ulice, kompletně zaplaven při rozsáhlé povodni. Materiál tak nyní prochází revizí a dochází také k digitalizaci inventárních záznamů. Výsledkem těchto procesů je i přesnější určení původních nálezů a nálezových situací (publikace kachlových reliéfu napřs. Menoušková 2011, 161-173; 2012, 217-225; 2016, 151-159; publikace středohradištních nálezů např. Frolíková-Kaliszová 2002, 163-166; 2003, 553-560; 2004, 75-80; 2020, 785-807).
} 


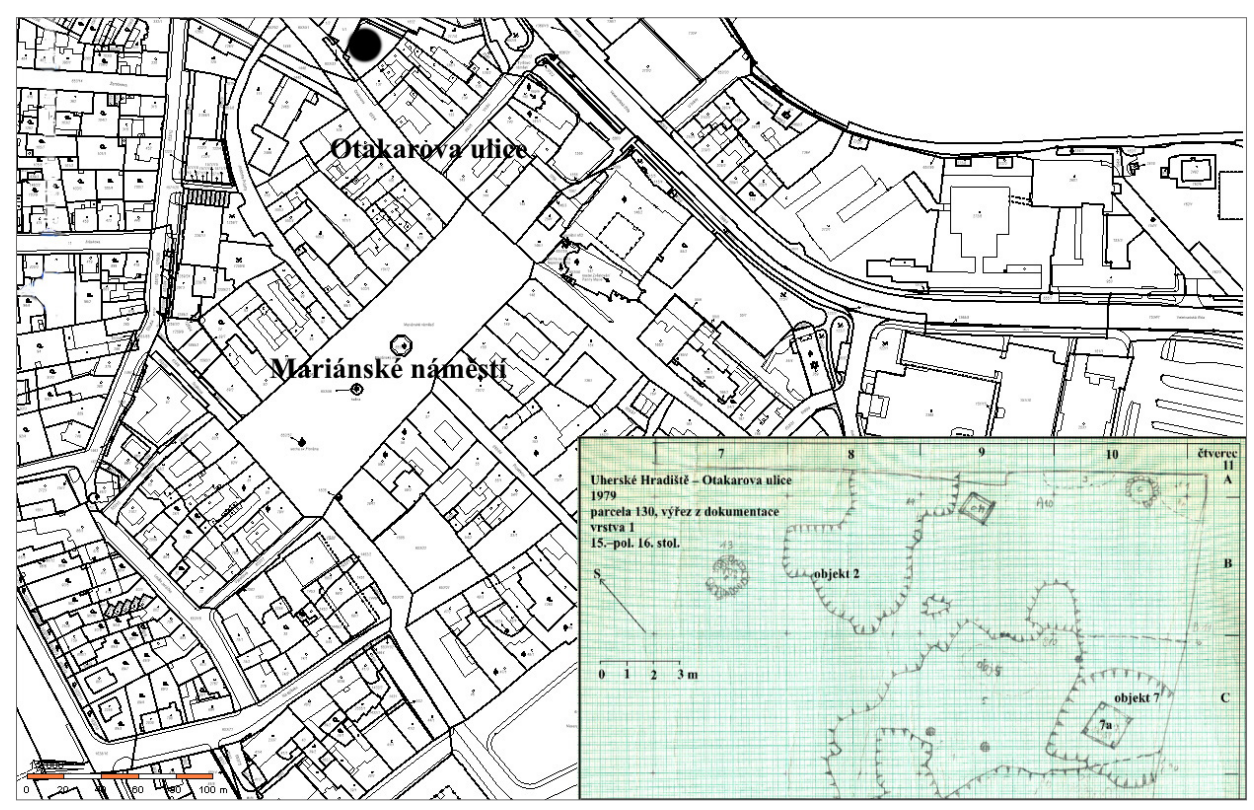

Obr. 1. Místo nálezu kachlů na výseku z mapy Uherského Hradiště a část plánové dokumentace výzkumu v Uherském Hradišti, Otakarově ulici. Vyznačeny objekty 2 a 7 . Digitální úprava D. Menoušková.

Abb. 1. Fundort der Kacheln auf einem Kartenausschnitt von Uherské Hradiště und ein Teil der Plandokumentation der Grabung in Uherské Hradiště, Otakarova-Straße. Gekennzeichnet sind die Objekte 2 und 7. Digitale Aufbereitung D. Menoušková.

hrnčířských dílen na zájmové ploše nepřímo potvrdil i zmiňovaný archeologický výzkum Slováckého muzea, když z lokality doložil rozsáhlá střepiště a souvrství s hrnčířským odpadem z 16. a 17. století (objekty 1, 2, 3, 4, 5, 7 a 8). Zvláště v severní a severovýchodní části přecházela vrstva keramiky ve velké střepiště (pozůstatek hrnčířské výroby).

Zlomky kachlů s mitrou, berlou a nápisovou páskou byly získány z objektů 2 a 7 (obr. 2-4). V případě objektu 2 se jednalo o odpad z hrnčířských pecí, který R. Procházka (1979-1981 rkp. Terénního deníku) datuje do přelomu 15. a 16. století až do první poloviny 16. století. Šlo o rozsáhlý objekt (o rozměrech $4 \times 6 \mathrm{~m}$ ), který se nacházel ve východní části plochy a byl mísovitě zahlouben. Výplň objektu byla homogenní, v menší míře tvořily prríměs zvířecí kosti a železné předměty promísené černou hlínou. Keramika byla nejvíce kumulována v horní vrstvě, a to do hloubky $70-80 \mathrm{~cm}$ od začištěného povrchu. Z objektu bylo získáno 29 ks kachlů, mezi nimi i jeden s motivem biskupské mitry, berly a nápisové pásky.

Druhým objektem, z něhož byl fragment téhož kachlového motivu získán, je objekt 7 . Zlomek kachle z tohoto objektu je na zadní straně zakouřený, vzhledem k jeho torzovitosti nelze ale jednoznačně stanovit, zda je zakouření důsledkem použití v kamnovém tělese, či zda byl exemplář poškozen při výpalu. Objekt 7, z něhož kus pochází, byl velmi bohatý na materiál. Obsahoval původně 665 ks zlomků kachlů, z nichž se do současnosti dochovalo 487 kusů. Také tento objekt je datován podobně, do konce 15. až přelomu 15. a 16. století. Jednalo se o odpadní jámu půdorysu nepravidelného čtyřúhelníku $(3,8 \times 3,5 \times 1,8 \times 2,4 \mathrm{~m})$ a hloubky $1-1,3 \mathrm{~m}$ se zaoblenými rohy a nerovnými stěnami. Objekt byl zřejmě zahlouben do východní části maltové kry. Ta byla doložena na východním profilu. Výplň objektu tvořila černá hlína hojně promísená keramikou (původně až 2098 ks), kachli (původně 665 kusů), železnými artefakty (původně 223 zlomků), zviŕrecími kostmi (666 kusů), zlomky cihel, dlaždic, zbytky malty apod. V detailnější interpretaci odpadního objektu 7 jsme ovšem limitováni faktem, že ačkoli byl prozkoumán v úplnosti, jeho obsah dosud nebyl v úplnosti vyhodnocen (i vzhledem $\mathrm{k}$ absenci nálezové zprávy). Přesto je 


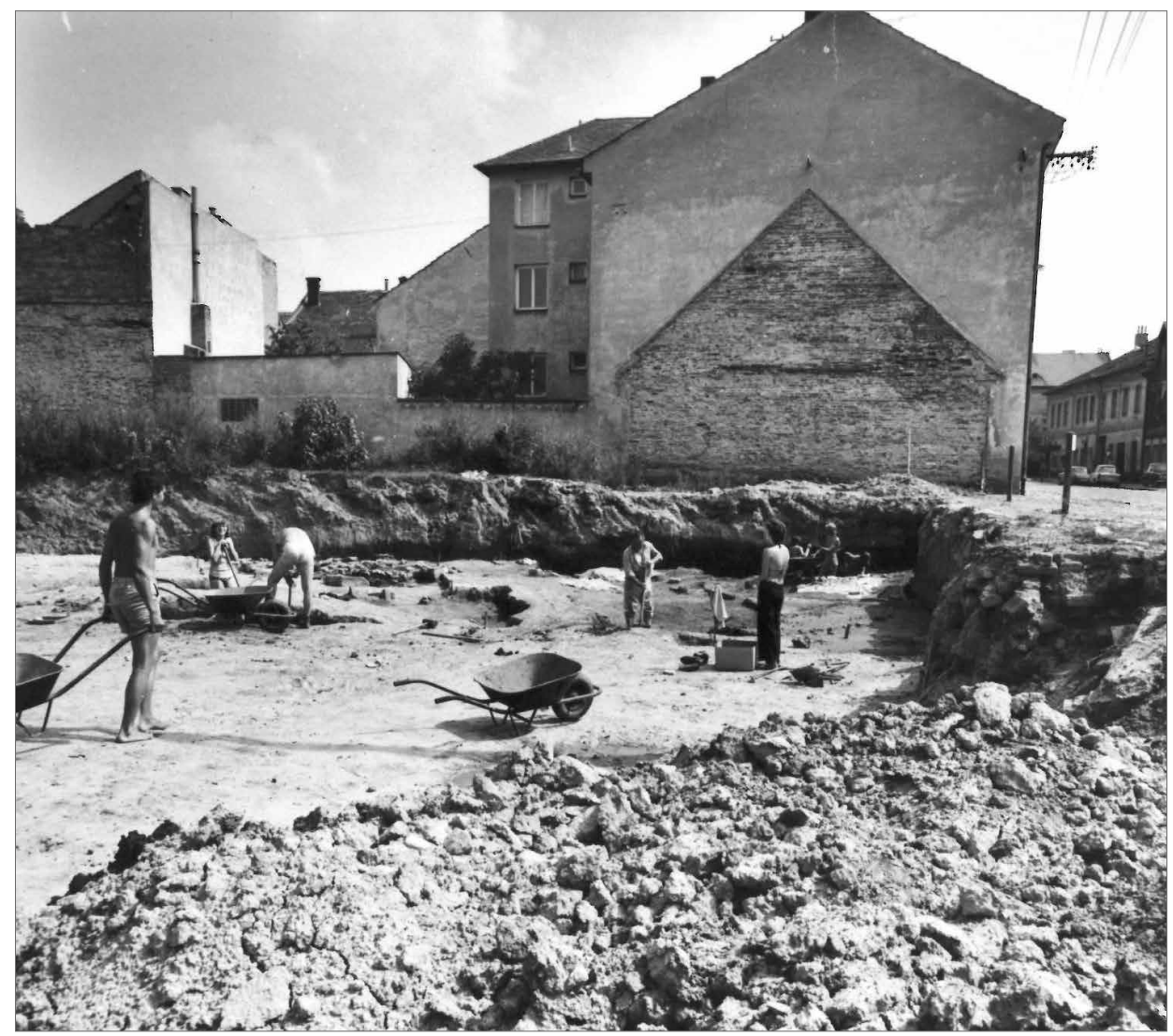

Obr. 2. Pohled na jižní polovinu zkoumané plochy (s objekty 2 a 7) na ulici Otakarově v roce 1979. Foto fotoarchiv Slováckého muzea v Uherském Hradišti, autoři R. Snášil a L. Chvalkovský.

Abb. 2. Blick auf die Südhälfte der untersuchten Fläche (mit den Objekten 2 und 7) in der Otakarova-Str. im Jahr 1979. Foto Fotoarchiv des Museums der mährischen Slowakei in Uherské Hradiště, Foto R. Snášil und L. Chvalkovský.

možné s ohledem na charakter výplně objektu vyslovit hypotézu, že sloužil patrně k uložení nejen odpadu z hrnčířské dílny, ale i odpadu z domácnosti/í. Zpracování kachlového materiálu, které nyní probíhá, ukazuje, že některé kusy z tohoto objektu nesou stopy zakouření (nikoli ovšem stopy omazu či jiné doklady po zasazení do př́padného kamnového tělesa). Většina z ikonografických motivů je $\mathrm{v}$ tomto objektu zastoupena jen $\mathrm{v}$ jednotkách kusů (podobně jako reliéf s motivem biskupské mitry, berly a nápisové pásky). $\mathrm{V}$ případě, že by se jednalo o odpad z doslouživších kamen, byl by počet nálezů nutně větší a také rozměrově a stylisticky by si byly bližší.

\section{Ikonografická a epigrafická analýza motivu}

Z kachlů s motivem, který je předmětem našeho zájmu, se dochovaly dva torzálně zachované kusy čelní vyhř́ivací stěny (podrobněji viz tab. 1); kachel měl původně patrně výškový formát a poloválcovou komoru. Z objektu č. 7 (obr. 5) pochází menší zlomek, inv. č. A 56085, a z objektu č. 2 se zachoval větší, zčásti rekonstruovaný a lépe vypovídající kus, inv. č. A 63471, zachycující přibližně horní polovinu kachle (obr. 6-7). Ikonografie obou dochovaných kachlů je totožná. Reliéf $\mathrm{z}$ lépe dochovaného exempláře ukazuje $\mathrm{v}$ jednoduché hranolové liště dobře otištěný, byt' výtvarně stř́idmě zpracovaný motiv, $\mathrm{v}$ jehož centru se dochovala mitra s biskupskou berlou. $\mathrm{Z}$ vrcholu 


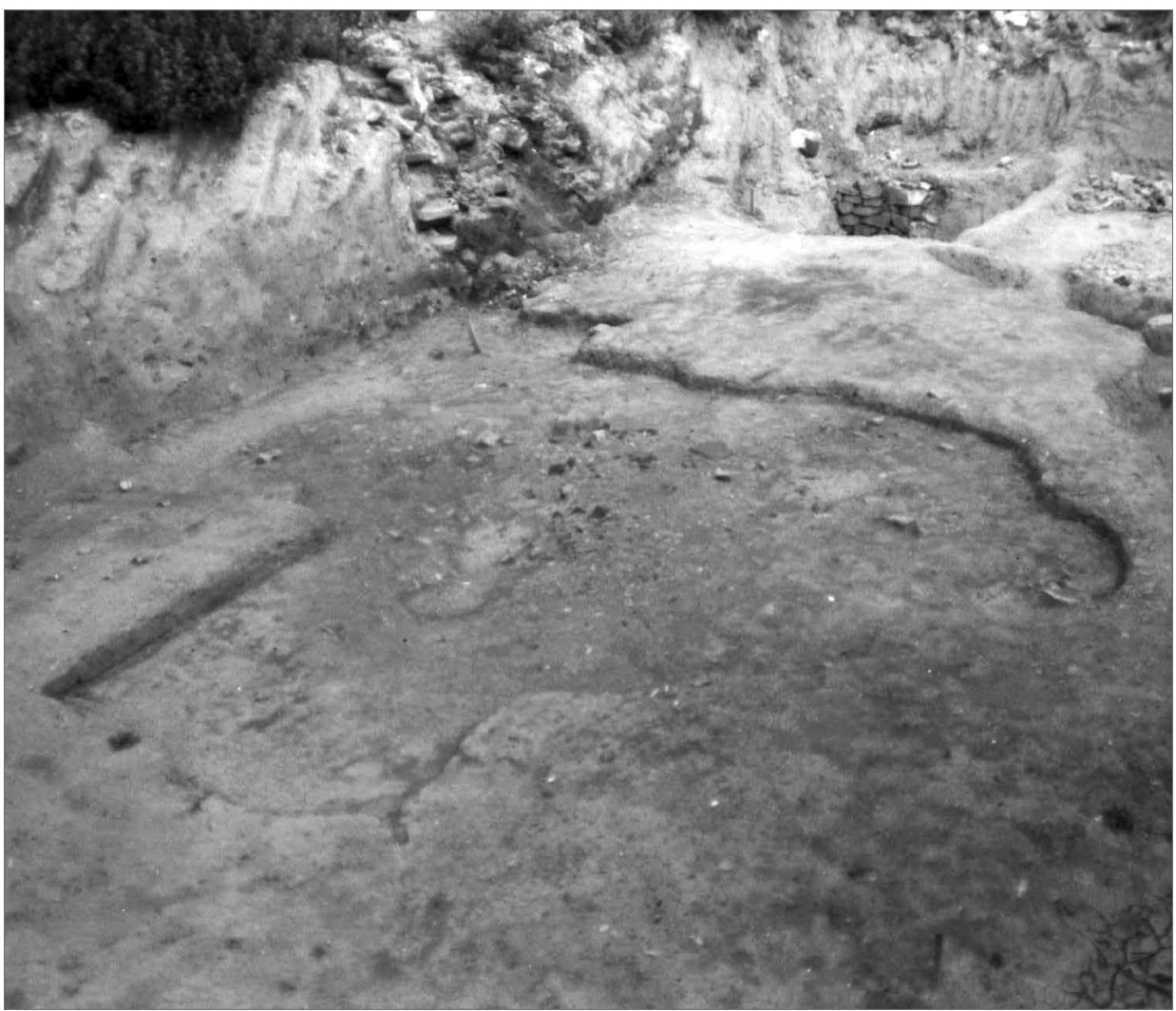

Obr. 3. Pohled na vypreparovaný objekt 2, střepoviště nepravidelného tvaru. Pohled od západu, 1979. Foto fotoarchiv Slováckého muzea v Uherském Hradišti, autoři R. Snášil a L. Chvalkovský.

Abb. 3. Blick auf das präparierte Objekt 2, Scherbenfeld von unregelmäßiger Form. Blick von Westen, 1979. Foto Fotoarchiv des Museums der mährischen Slowakei in Uherské Hradiště, Foto R. Snášil und L. Chvalkovský.

mitry vychází na obě strany skládaná nápisová páska se zkratkovitým latinským nápisem, oba její konce směřují do středu kachle, kde se původně nacházel kolčí (?) štít se znakem. Ze spodních okrajů mitry vycházejí dvě stuhy, které nápisovou pásku kř́žží a klenou se do rohů štítu. Znak na štítě je bohužel z větší části odlomen. V pravé části reliéfu se dochovalo pouze jeho torzo.

Mitra, biskupská hůl, latinský zkratkovitý text na nápisové pásce i torzálně zachovaný reliéf znaku ukazují, že reliéf kombinuje prvky liturgické s heraldickými, aniž by heraldická pravidla striktně dodržoval. Zobrazení mitry (infule) z horního středu scény je tak především výsledkem snah o výstižné vyjádření liturgického významu a výtvarnou vyváženost kusu než snahy o heraldickou přesnost (mitra by měla být na heraldicky pravé straně horní hrany štítu, kde nahrazuje hodnostní korunu šlechty, jejím heraldickým protějškem je pak berla; Buben 2003, 289-291; 67-68). Mitra jako liturgická pokrývka hlavy sloužila především papeži, kardinálům, patriarchům, arcibiskupům a biskupům, s jistým omezením pak i kanovníkům, opatům, infulovaným převorům a prelátům, a to jako odznak jejich úřadu či hodnosti. Je chápána jako helmice spásy a její dva hroty (naznačené i na našem reliéfu) značí Starý a Nový zákon (Buben, tamtéž). Ze zadního spodního okraje mitry vycházejí dvě zpravidla stř́ibrné stuhy (fimbrie) zlatě lemované se zlatým třepením na koncích. Stuhy v našem případě nespadají na šíji nositele, nýbrž překrývají nápisové pásky a klenou se $\mathrm{k}$ rohům zachovaného štítu. Tam byly patrně oba konce zakončeny třepením. 


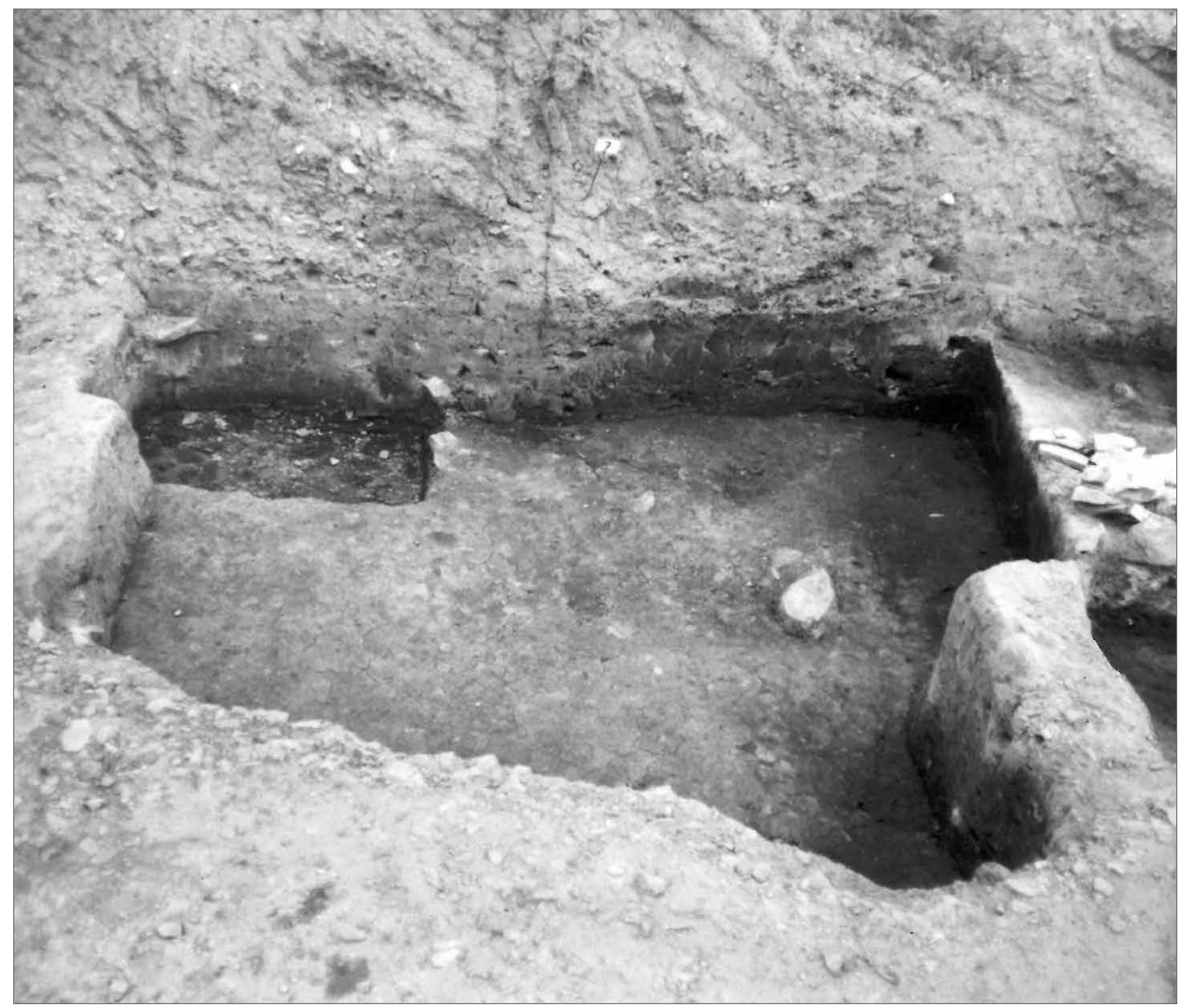

Obr. 4. Pohled na vypreparovaný objekt 7, odpadní jámu. Pohled od severozápadu, 1979. Foto fotoarchiv Slováckého muzea v Uherském Hradišti, autoři R. Snášil a L. Chvalkovský.

Abb. 4. Blick auf das präparierte Objekt 7, Abfallgrube. Blick von Nordwest, 1979. Foto Fotoarchiv des Museums der mährischen Slowakei in Uherské Hradiště, Foto R. Snášil und L. Chvalkovský.

Spolu s mitrou je zobrazena hlavice berly - pastýřské hole (pastorale). Berla byla odznakem pastýřského úřadu a jurisdikce biskupa, opata či abatyše (Buben 2003, 67-68). Byla symbolem důstojnosti církevních hodnostářù. $V$ našem případě je zachovaná především její hlavice - na způsob šneku dovnitř zahnutá a tvarově bohatě zdobená. Je ztvárněna před mitrou, když tuto symetricky dělí na dvě části. Berla, respektive její hlavice, je zobrazena bez sudaria, které bývá vyhrazeno opatům, převorům či abatyším.

Dalším důležitým prvkem, který vede k atribuci tohoto reliéfu, je torzo znaku v dolním rohu nejlépe zachovaného kusu. Odlomený hrot, který je na reliéfu viditelný, je patrně jedním ze tří hrotů šípů z osobního znaku Jana Filipce (obr. 8-9).

Heraldické a následně epigrafické analýzy motivu kachle od Tomáše Sternecka, Jana Štěpána a Dalibora Havla ${ }^{4}$ charakterizují reliéf takto: nad horní částí torza heraldického štítu je biskupská mitra, za ní vršek berly, mitru obepíná skládaná nápisová páska ve tvaru obráceného rovnoramenného trojúhelníku se základnou nahoře a hlavním vrcholem skrytým za hlavou štítu. Nápis začíná na heraldicky pravém okraji základny, pokračuje ve směru hodinových ručiček a vyplňuje celou pásku: $R$ in xpo $p$ d ep // wrd(e) ecl dei // „g ioannes“. Čtení části „g.ioannes“

4 Velké díky za zprostředkování analýz a jejich koordinaci patři Haně Jordánkové z Archivu města Brna. Dalši poděkování míři k Tomáši Sterneckovi z Historického ústavu AV ČR, v. v. i, pobočka České Budějovice, Janu Štěpánovi ze Zemského archivu v Opavě, pobočka Olomouc, a Daliboru Havlovi z Ústavu pomocných věd historických a archivnictví FF MU, Brno, za jejich konzultace a pomoc. 
Tab. 1. Zlomky kachlů s motivem biskupské mitry, berly a nápisové pásky s textem z Uherského Hradiště, Otakarovy ulice (uloženo Slovácké muzeum v Uherském Hradišti).

Tab. 1. Kachelfragmente mit dem Motiv einer Bischofsmitra, eines Krummstabs und Inschriftbandes mit Text aus Uherské Hradiště, Otakarova-Str. (aufbewahrt im Museum der mährischen Slowakei in Uherské Hradiště).

\begin{tabular}{|c|c|c|c|c|c|}
\hline $\begin{array}{l}\text { Inv. } \\
\text { č. kusu }\end{array}$ & Obj. & Zlomek & Ikonografie & Typ, lišta, materiál, technologie & Rozměry \\
\hline A 56085 & 7 & $\begin{array}{l}\text { levý horní } \\
\text { roh ČVS } \\
\text { s reliéfem }\end{array}$ & $\begin{array}{l}\text { část mitry s berlou a skládanou } \\
\text { nápisovou páskou } \\
\text { se zkratkovitým latinským } \\
\text { minuskulním nápisem }\end{array}$ & $\begin{array}{l}\text { torzo } \\
\text { lišta jednoduchá, hranolová } \\
\text { dobře, tvrdě do okrových až } \\
\text { okrovo-šedých tónů vypálený } \\
\text { jemný hlinitopísčitý materiál, } \\
\text { lom slinutý, vzadu stopy } \\
\text { zakouření a prstování, kvalitně } \\
\text { zpracované těsto, ostrý detail, } \\
\text { tvrdý výpal }\end{array}$ & $\begin{array}{l}\max . \mathrm{v} .120 \mathrm{~mm} \\
\text { s. } 133 \mathrm{~mm}, \\
\text { náběh na ko- } \\
\text { moru } 27 \mathrm{~mm} \text {, } \\
\text { s. } 6-10 \mathrm{~mm}\end{array}$ \\
\hline A 63471 & 2 & $\begin{array}{l}\text { přibližně } \\
\text { polovina } \\
\text { reliéfu kachle } \\
\text { z horní části } \\
\text { kusu s částí } \\
\text { půlválcové ko- } \\
\text { mory, slepeno } \\
\text { z více částí, } \\
\text { doplňováno }\end{array}$ & $\begin{array}{l}\text { reliéf s mitrou, biskup- } \\
\text { skou berlou, nápisovou páskou } \\
\text { a torzem znaku; z vrcholu mitry } \\
\text { vychází na obě strany skládaná } \\
\text { nápisová páska se zkratkovitým } \\
\text { latinským, převážně minuskul- } \\
\text { ním nápisem, oba její konce } \\
\text { směřuí do středu kachle, kde se } \\
\text { původně nacházel kolčí (?) štít } \\
\text { se znakem; ze spodních okrajů } \\
\text { mitry vycházejí dvě stuhy, které } \\
\text { nápisovou pásku kříží a klenou } \\
\text { se do rohů štítu; znak na štítě } \\
\text { zachován jen v torzu v pravé } \\
\text { části reliéfu, patrně hrot jed- } \\
\text { noho ze tří šípů ze znaku Jana } \\
\text { Filipce }\end{array}$ & $\begin{array}{l}\text { horní (přibližně) polovina ko- } \\
\text { morového kachle s půlválcovou } \\
\text { komorou } \\
\text { lišta jednoduchá, masivní, } \\
\text { hranolová, poškozená } \\
\text { dobře, tvrdě do cihlovo- } \\
\text { okrových až cihlovo-okrovo- } \\
\text { šedých tónů vypálený jemný } \\
\text { hlinitopísčitý materiál, lom } \\
\text { slinutý, torzo bez dochovaného } \\
\text { ZO, v půlválcové komoře patrný } \\
\text { okraj původního otvoru, komora } \\
\text { z vnější strany nepravidelně } \\
\text { zabarvená, viditelné tahy prstů, } \\
\text { kvalitně zpracované těsto, ostrý } \\
\text { detail, tvrdý výpal }\end{array}$ & $\begin{array}{l}\text { v. max. } 215 \mathrm{~mm} \text {, } \\
\text { š. } 220-225 \mathrm{~mm} \text {, } \\
\text { hl. komory } \\
\text { (celá) } 113 \mathrm{~mm} \text {, } \\
\text { s. } 5-15 \mathrm{~mm}\end{array}$ \\
\hline
\end{tabular}
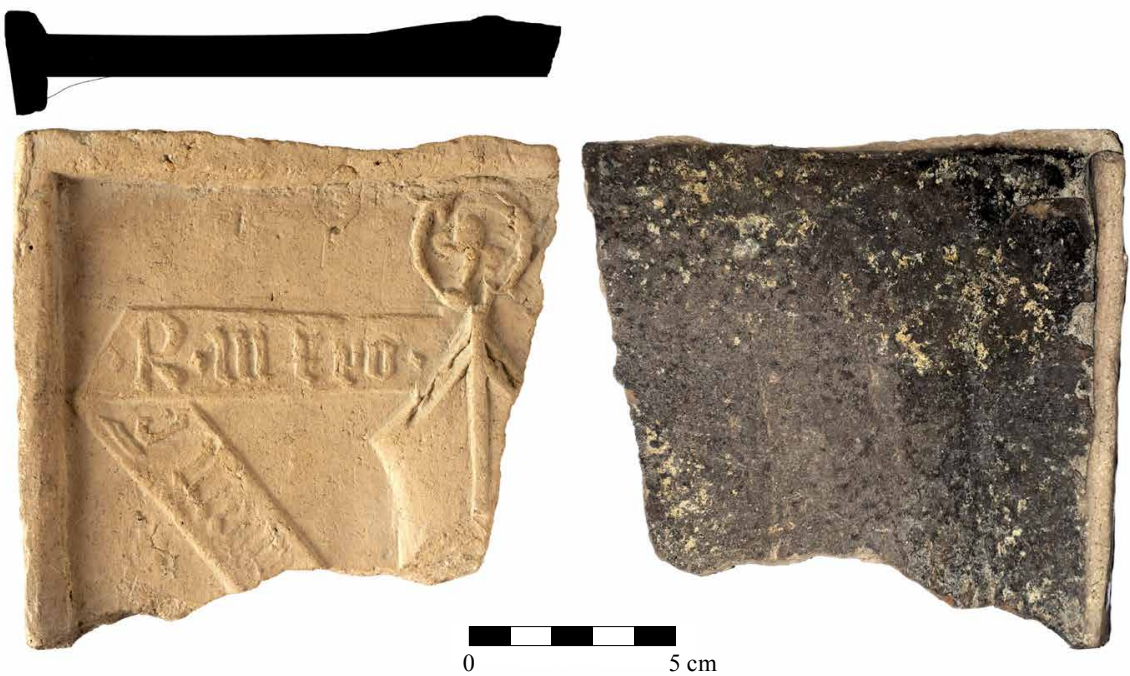

Obr. 5. Torzo kachle s motivem mitry, berly a nápisové pásky, inv. č. A 56085, z objektu 7. Přední a zadní strana. Foto T. Heřmánek, grafická úprava D. Menoušková.

Abb. 5. Kacheltorso mit Motiv einer Mitra, eines Krummstabs und Inschriftbandes, Inv.-Nr. A 56085, aus Objekt 7. Vorderund Rückseite. Foto T. Heřmánek, grafische Bearbeitung D. Menoušková. 

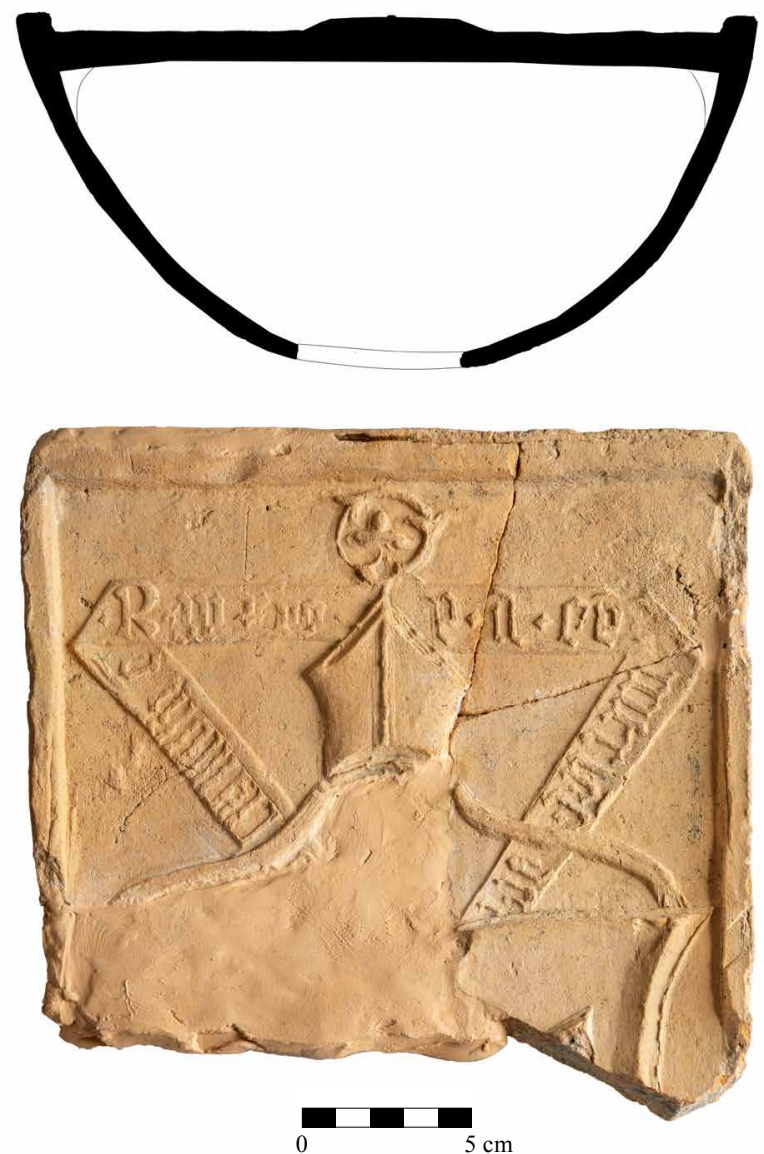

Obr. 6. Torzo kachle s motivem mitry, berly a nápisové pásky, inv. č. A 63471, z objektu 2. Foto T. Heřmánek, grafická úprava D. Menoušková.

Abb. 6. Kacheltorso mit Motiv einer Mitra, eines Krummstabs und Inschriftbandes, Inv.-Nr. A 63471, aus Objekt 2. Foto T. Heřmánek, grafische Bearbeitung D. Menoušková.

je ovšem hypotetické podle reálií a s ohledem na jiné památky. Přepis textu z nápisové pásky zní: „Reverendus in Christo pater dominus episcopus Waradiensis ecclesiae Dei gratia / Ioannes etc. /“V překladu tedy: „Důstojný v Kristu otec pan biskup kostela varadínského z Boži milosti / Jan atd. /“

Takto ztvárněný reliéf je dosti ojedinělý a nemá v českém, moravském, slezském a potažmo slovenském kachlovém materiálu adekvátní analogii (srovnej např. Brych 2004; Frolík 2003; Havlice-Kypta et al. 2017; Jiřík-Kypta edd. 2013; Kvietok-Mácelová 2013; Menoušková-Měřínský edd. 2008; Moravec 2019; Pavlík 2017; Pavlík-Vitanovský 2004). Lze uvést některé vzdálenější a volněji zpracované reliéfy (obr. 10-11): ze severního Německa novodobě podle původní matrice formovaný motiv s biskupským znakem lübeckého biskupa Grimmolta (1510-1523) z muzea v Lübecku (Strauss 1972, II. Teil, 132, Tafel 78, Nr. 3) nebo pak z Kolína nad Rýnem zeleně glazovaný „portrétní“ reliéf s postavou biskupa a bohatou výzdobou z druhé poloviny 16. století (Strauss 1972, II. Teil, 148, Tafel 135, Nr. 2). Z polského materiálu (obr. 12-14) je možné uvést rozměrově menší režný kus se čtyřmi medailonky s heraldickými znaky, mezi nimiž se objevuje 


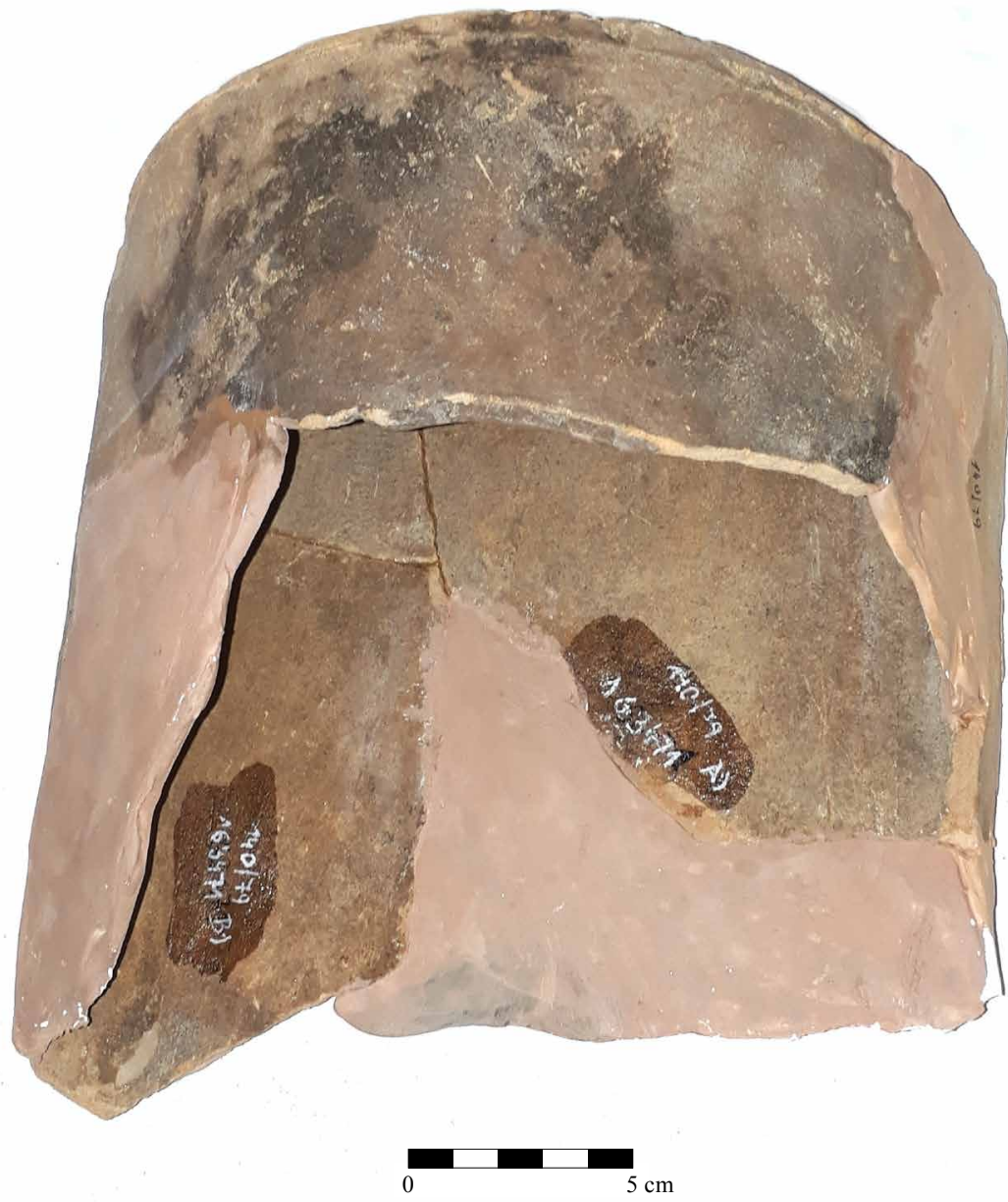

Obr. 7. Torzo půlválcové komory kachle s motivem mitry, berly a nápisové pásky, inv. č. A 63471, z objektu 2. Foto D. Menoušková.

Abb. 7. Torso einer halbzylindrischen Blattkachel mit Motiv einer Mitra, eines Krummstabs und Inschriftbandes, Inv.Nr. A 63471, aus Objekt 2. Foto D. Menoušková.

i znak arcibiskupa Jana Sprowského (1453-1464) z lokality Jankowo Dolne (Janiak 2003, 75, katalog II.105), dále opět drobnější, černě glazovaný exemplář se znakem arcibiskupa Wincentyho Kota (1437-1448) z Hnězdna (Janiak 2003, 79, katalog II.120) či zlomek opět rozměrově výrazně menšího kachle se znakem arcibiskupa Jana Gruszczyńského (1464-1473) s mitrou, jetelovým křížem a berlou také z Hnězdna (Janiak 2003, 79, katalog II.121). Ani z širšího uherského prostředí, které bylo s osudy Jana Filipce př́ímo spojeno, nebylo publikováno adekvátnější srovnání, a lze tak poukázat pouze na zeleně glazovaný fragment s reliéfem hlavy biskupa z hradu Varaždín (dnes na území Chorvatska; Gruia 2013, 497, kat. 418) datovaný do doby kolem roku 1500 (obr. 15). Stylizace všech výše uvedených reliéfů je však uherskohradišt'skému kusu dosti vzdálená, a př́mou analogii tak v kachlovém materiálu postrádáme.

Motiv z Uherského Hradiště je v širším slova smyslu odrazem politické a kulturní situace, vlivem níž se Morava, Slezsko a Horní a Dolní Lužice dostaly v letech 1469-1490 pod vládu krále 


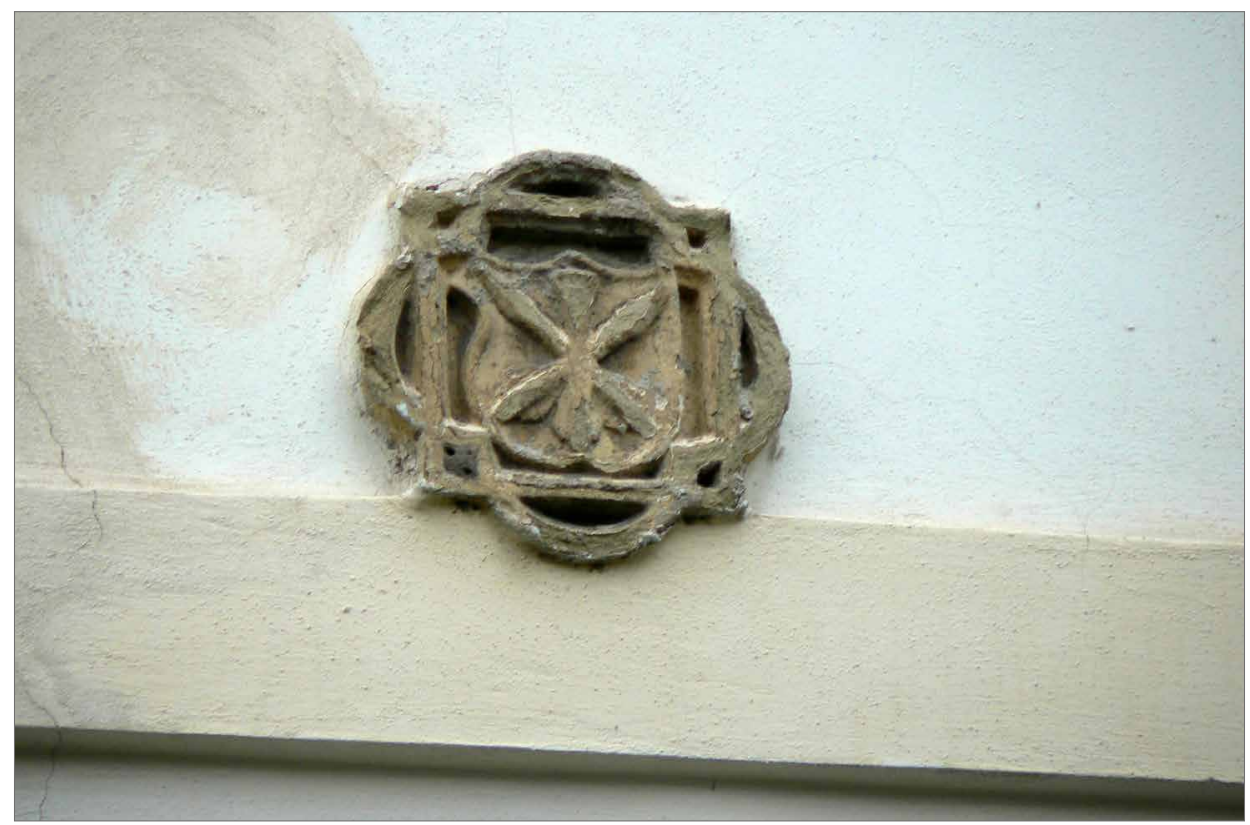

Obr. 8. Znak Jana Filipce ve vnějším východním zdivu františkánského kláštera v Uherském Hradišti. Foto D. Menoušková. Abb. 8. Emblem von Johann Filipec an der östlichen Außenwand des Franziskanerklosters in Uherské Hradiště. Foto D. Menoušková.

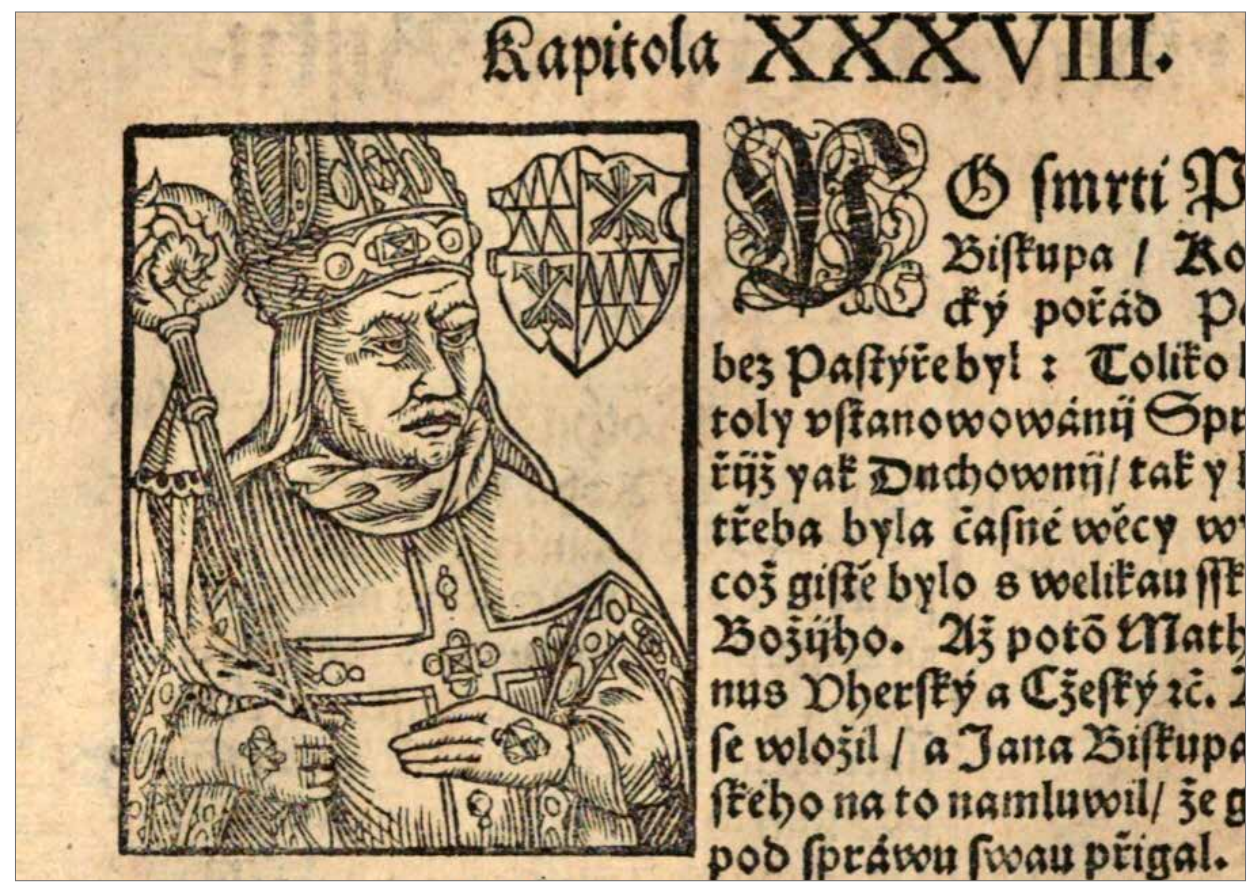

Obr. 9. Detail vyobrazení Jana Filipce s biskupským znakem. Podle Paprocký 1593.

Abb. 9. Detail einer Abbildung von Johann Filipec mit Bischofsemblem. Nach Paprocký 1593. 


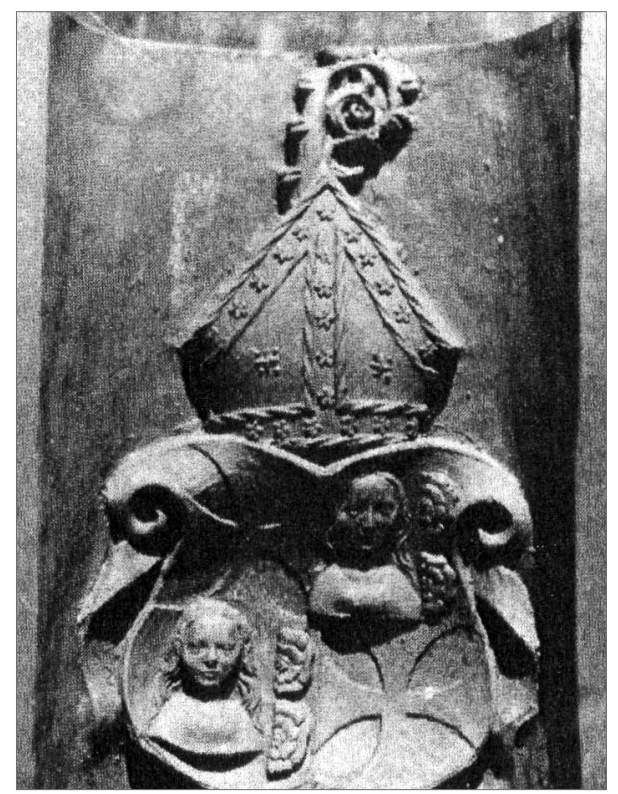

Obr. 10. Heraldický motiv s biskupským znakem lübeckého biskupa Grimmolta (1510-1523) z muzea v Lübecku. Podle Strauss 1972, II. Teil, 132, Tafel 78, Nr. 3.

Abb. 10. Heraldisches Motiv mit Bischofsemblem des Lübecker Bischofs Grimmolt (1510-1523) aus einem Museum in Lübeck. Nach Strauss 1972, II. Teil, 132, Tafel 78, Nr. 3.

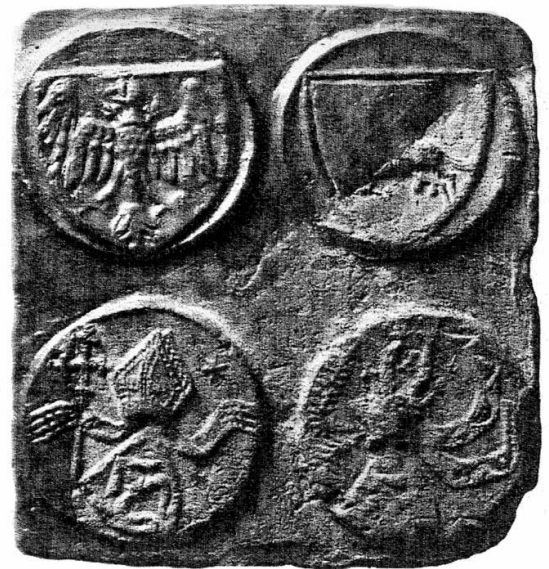

Obr. 12. Kachel se ětyřmi medailonky s heraldickými znaky, mezi nimiž je i znak arcibiskupa Jana Sprowského (1453-1464) z lokality Jankowo Dolne. Podle Janiak 2003, 75, katalog II.105.

Abb. 12. Kachel mit vier Medaillons mit heraldischen Zeichen, darunter auch das Emblem von Erzbischof Jan Sprowski (1453-1464) von der Fundstelle Jankowo Dolne. Nach Janiak 2003, 75, Katalog II.105.

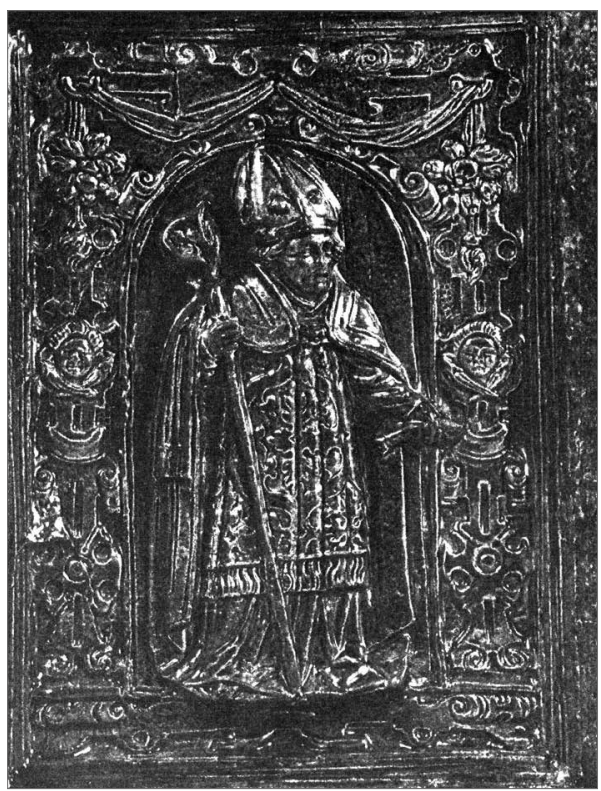

Obr. 11. Zeleně glazovaný reliéf s postavou biskupa a bohatou výzdobou z druhé poloviny 16. století z Kolína nad Rýnem. Podle Strauss 1972, II. Teil, 148, Tafel 135, Nr. 2.

Abb. 11. Grünglasiertes Reilief mit Bischofsfigur und reicher Verzierung aus der zweiten Hälfte des 16. Jahrhunderts aus Köln am Rhein. Nach Strauss 1972, II. Teil, 148, Tafel 135, Nr. 2.

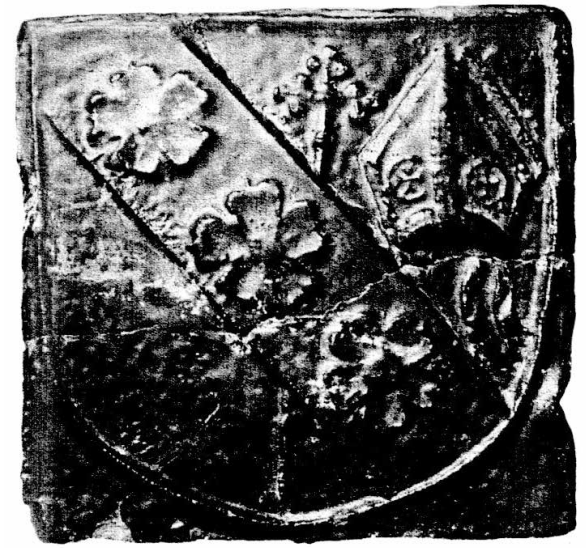

Obr. 13. Glazovaný kachel se znakem arcibiskupa Wincentyho Kota (1437-1448) z Hnězdna. Podle Janiak 2003, 79, katalog II.120.

Abb. 13. Glasierte Kachel mit dem Emblem von Erzbischof Wincenty Kot (1437-1448) aus Gnesen. Nach Janiak 2003, 79, Katalog II.120. 


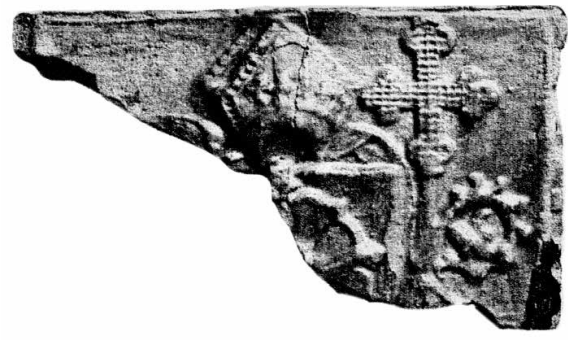

Obr. 14. Část reliéfu kachle se znakem arcibiskupa Jana Gruszczyńského (1464-1473) s mitrou, jetelovým kř́ížem a berlou z Hnězdna. Podle Janiak 2003, 79, katalog II.121.

Abb. 14. Teil des Reliefs einer Kachel mit dem Emblem von Erzbischof Jan Gruszczyński (1464-1473) mit Mitra, Kleeblattkreuz und Krummstab aus Gnesen. Nach Janiak 2003, 79, Katalog II.121.

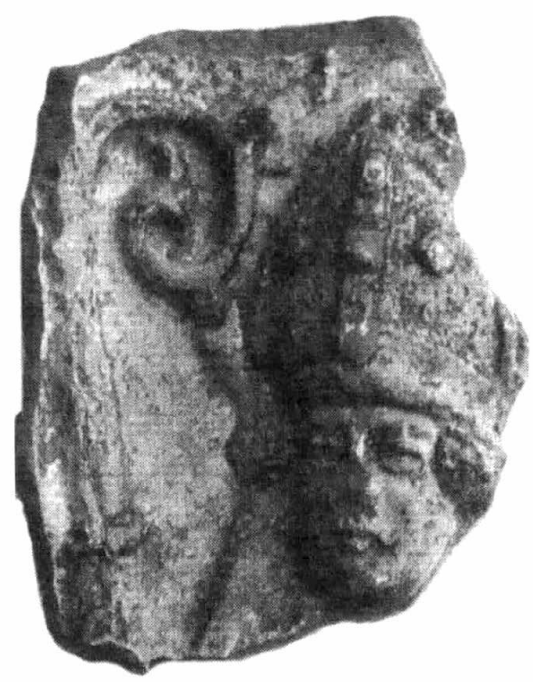

Obr. 15. Zeleně glazovaný fragment s reliéfem hlavy biskupa z hradu Varaždín. Podle Gruia 2013, 497, kat. 418.

Abb. 15. Grünglasiertes Fragment mit dem Relief des Kopfes eines Bischofs von Burg Varaždín. Nach Gruia 2013, 497, Kat. 418.
Matyáše Korvína. K tématu pronikání renesanční kultury a jejího nejstaršího zaalpského centra, které Matyáš Korvín v Uhrách vytvořil, se v obecnější rovině vyslovil již například Ivo Hlobil (1991), na vlivy budínského dvora na moravský (potažmo brněnský) kachlový materiál upozornili již dřive např́iklad Michna (1974, 179-205), Cejnková-Loskotová (1994, 181-188), Jordánková-Loskotová (2002, 555-587; 2005, 445-456) a Hložek-Jordánková-Loskotová $(2018,491-509)$. Čilé kulturní a hospodářské styky, které mezi Moravou a Uhrami již existovaly, se v období Matyášovy vlády ještě prohloubily. Docházelo tak nejen k těsnějšímu provázání osobních vazeb, ale také k posílení obchodu a řemesel. Významnými středisky oboustranných styků mezi Moravou a Slovenskem byla v té době slovenská Skalica a na druhé straně moravská Strážnice, která se stala místem pobytu moravských královských poslů (Měštánek 2003, 29-31). Stř́dmý, výtvarně lapidárně stylizovaný reliéf uherskohradišt'ského kachle tuto situaci odráží stylově (inklinací k renesančnímu ztvárnění) i historicky (zachycuje postavu dalekosáhle překračující hranice Moravy, přesto s úzkými vazbami k regionu). Také souvislosti a analogie k výtvarně svébytnému konceptu kachle lze najít především $\mathrm{v}$ regionálních památkách. Je mu blízký jednoduchý, renesancí již ovlivněný styl pískovcového náhrobníku biskupa Jana Filipce $^{5}$ ze sakristie františkánského kostela v Uherském Hradišti (obr. 16). Poukázat lze i na další kamenickou výzdobu z františkánského kláštera souvisící s Janem Filipcem. Je jím biskupská mitra $\mathrm{v}$ podřímsí jižní vnější stěny presbytáře, dále osobní znak Jana Filipce (tři zkřížené hroty šípů) a znak biskupské mitry na vnějším průčelí východního křídla kláštera ${ }^{6}$ (obr. 17-18).

\footnotetext{
5 Náhrobník vznikl až po Filipcově smrti ,podle vkusu tamějších františkánư“ jako dílo domácí produkce (Hlobil 1991, 330; viz též Pojsl 2013, obr. 174). Tvoří ho obdélná deska zdobená reliéfní postavou zakladatele kláštera s odznaky jeho biskupské hodnosti a rodinným znakem, třemi zkříženými šípy, vpravo dole. Za pozornost stojí srovnání textu náhrobníku s nápisem na reliéfu uherskohradišt’ského kachle. Náhrobník nese nápis: „Anno domini 1509 obiit reverendisimus in Christo pater frater Joannes quondam episcopus Varadiensis, hic tumulatus eis anima deo vivat" (např. Měšt’ánek 2003, 129-130).

6 Františkánský klášter v Uherském Hradišti byl založen v roce 1491 z Filipcova popudu a na základě jeho finančních darů. Někdejší správce olomouckého biskupství je zde také pochován. Pohřeb je zpravidla lokalizován do řeholní hrobky pod hlavní oltár františkánského kostela. Během archeologického výzkumu R. Snášila v prostoru rajského dvora byl objeven základ středověké samostatně stojící osmiboké věže s kaplí a v ní byly identifikovány lidské kosterní ostatky. Ty jsou R. Snášilem připisovány zakladateli kláštera J. Filipcovi (Snášil 1990-1991; 1991-1992, 117-129). Donaci kostela Zvěstování Panny Marie a kláštera připomínají v podřímsí jižní vnější stěny presbytáře kostela celkem tři znaky zakladatelů - biskupský znak Jana Filipce, kolčí štít s erbem cimbuří vladyckého rodu z Vojslavic (Václav z Vojslavic byl druhým manželem Filipcovy sestry Zuzany a otčímem Filipcova synovce Jana z Kunovic) a kolčí štít se znakem růže pána z Moravan, tehdejšího správce hradišt'ského kraje.
} 


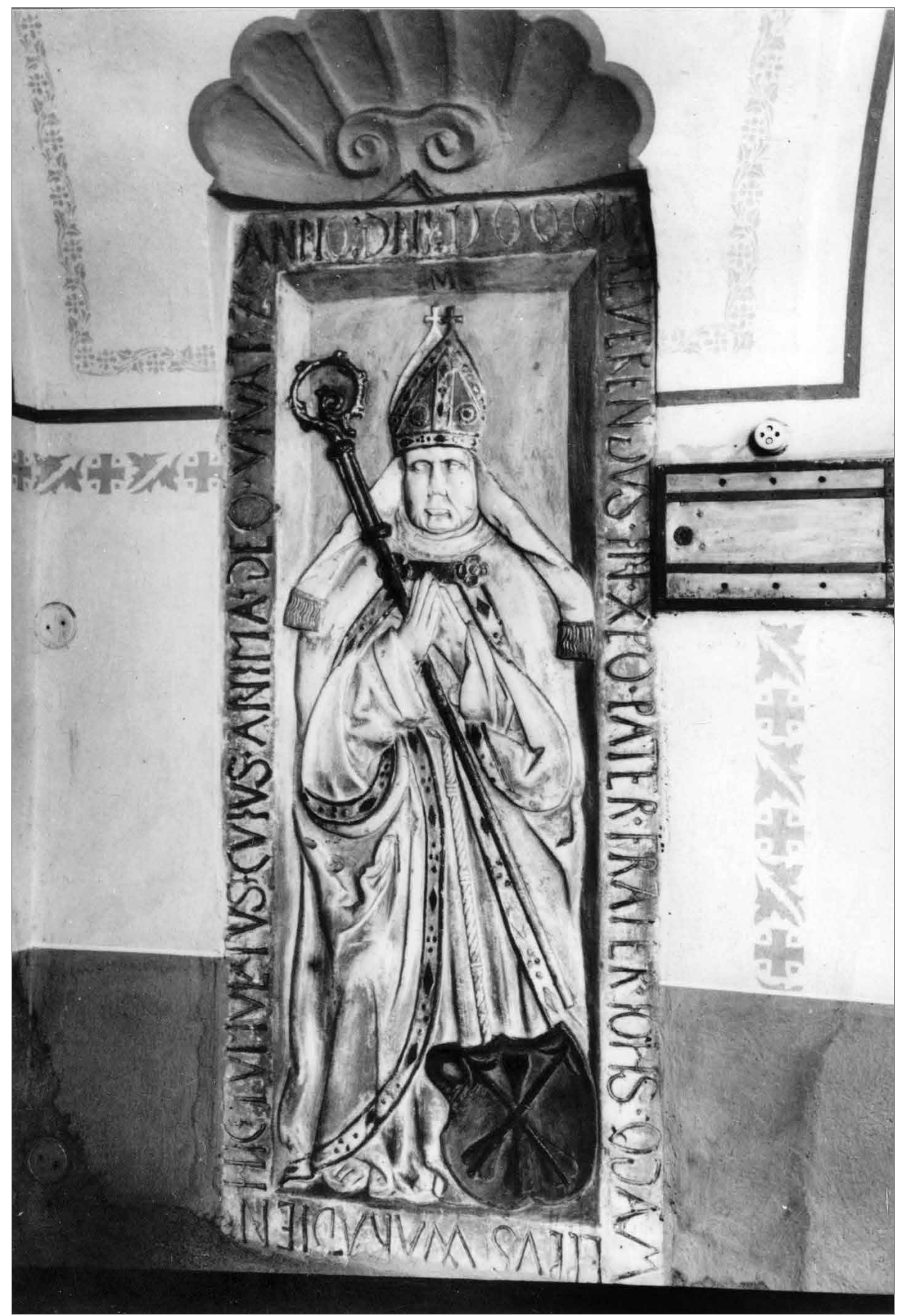

Obr. 16. Náhrobník Jana Filipce v sakristii františkánského kostela Zvěstování Panny Marie v Uherském Hradišti. Foto fotoarchiv Slováckého muzea v Uherském Hradišti, autor neznámý.

Abb. 16. Grabplatte von Johann Filipec in der Sakristei der Franziskanerkirche Mariä Himmelfahrt in Uherské Hradiště, Autor unbekannt. 


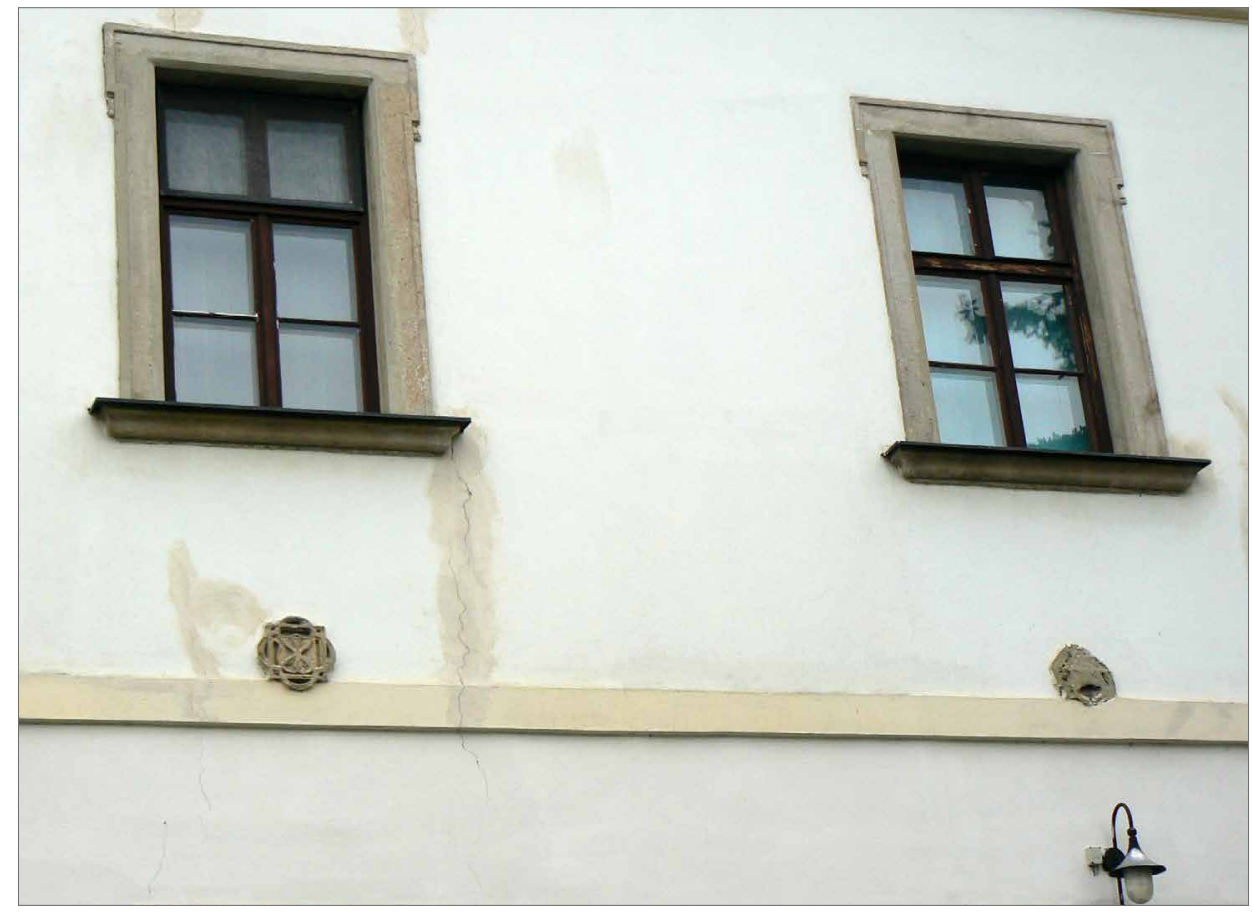

Obr. 17. Znak Jana Filipce a odznak biskupské mitry ve vnějším východním zdivu františkánského kláštera v Uherském Hradišti. Foto D. Menoušková.

Abb. 17. Emblem von Johann Filipec und Abzeichen der Bischofsmitra an der östlichen Außenwand des Franziskanerklosters in Uherské Hradiště. Foto D. Menoušková.

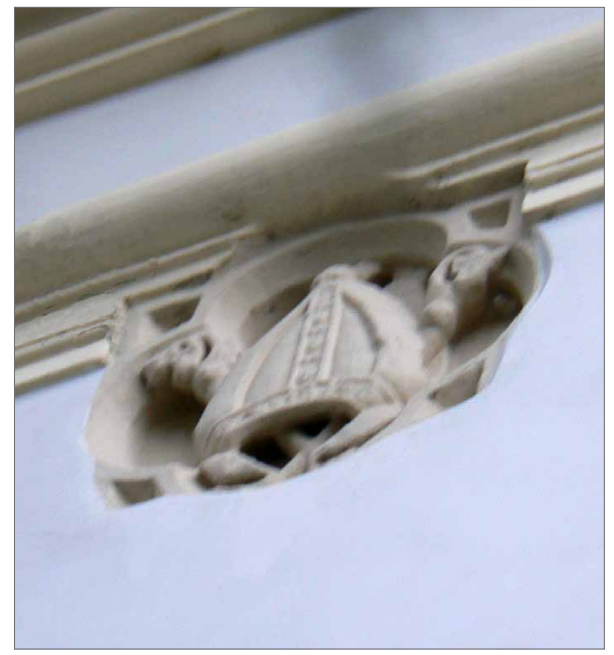

Obr. 18. Biskupská mitra na jižní, vnější straně presbyteria kostela při františkánském klášteře. Foto D. Menoušková.

Abb. 18. Bischofsmitra an der südlichen Außenwand des Chorraums der Kirche beim Franziskanerkloster. Foto D. Menoušková.
Historický exkurz: Jan Filipec a jeho vazby k moravsko-slovenskému pomezí

Velkovaradínský biskup, administrátor olomouckého biskupství a jeden z nejvýznamnějších diplomatů ve službách Matyáše Korvína Jan Filipec (asi 1431-1509), který se výrazně podílel na formování Matyášovy zahraniční politiky v 80 . letech 15 . století, započal svoji kariéru patrně ve službách moravského zemského hejtmana Jana Tovačovského z Cimburka jako písař (srov. Blahoslav 1458-1542; Hlobil 1991, 328-331; Foltýnová-Mikulcová 1999, 11-15; Měštánek 2003; Kalhous 2006). $\mathrm{Za}$ jeho diplomatickou kariérou v královské kanceláŕi a za jeho významným postavením u dvora Matyáše Korvína stály Filipcovy dobré znalosti moravské problematiky, jeho mimořádné schopnosti a politický přehled, $\mathrm{s}$ nímž přispěl i $\mathrm{k}$ mírovým rozhovorům a následnému urovnání situace roku 1478 mezi 


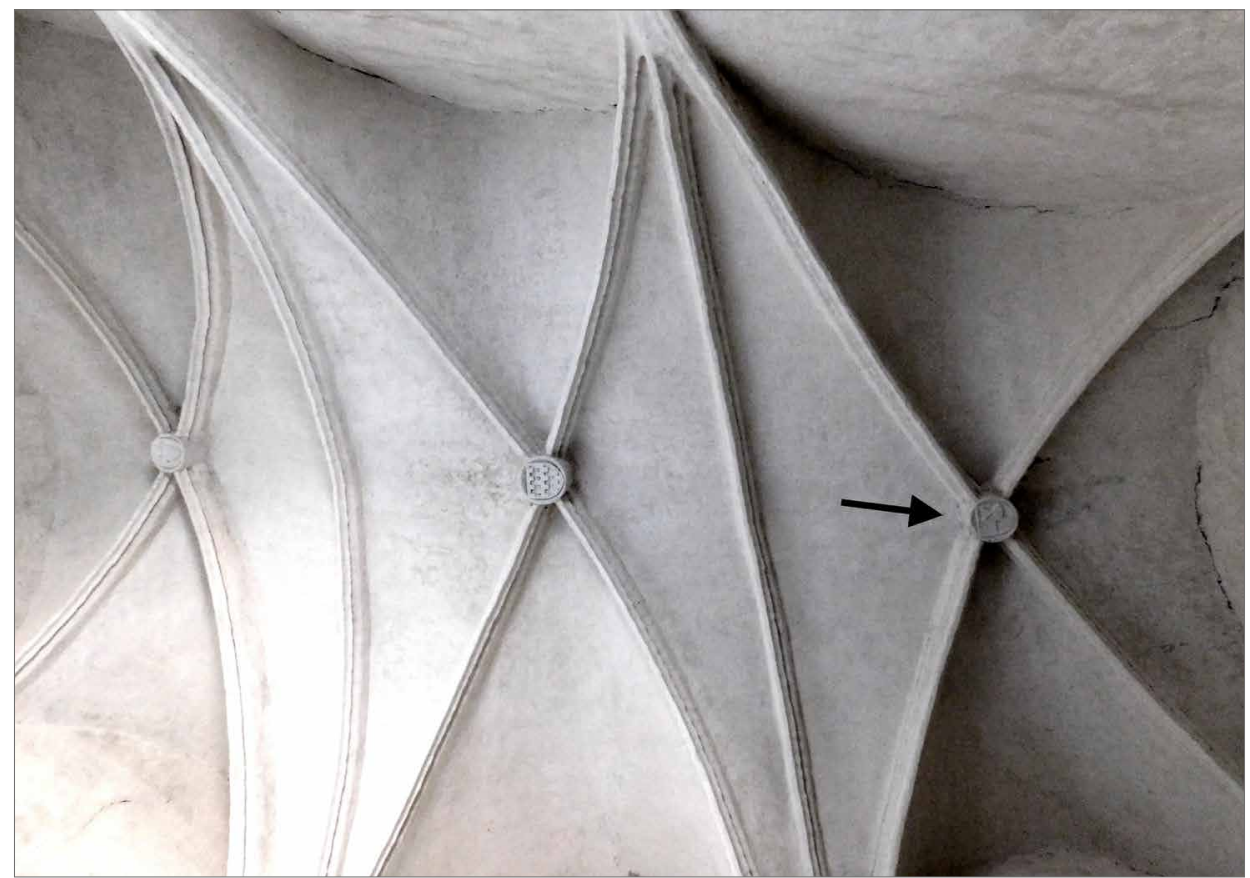

Obr. 19. Znaková galerie v tzv. zbrojnici hradu Buchlov se znakem Jana Filipce (označen šipkou). Foto R. Vrla.

Abb. 19. Wappengalerie im sog. Zeughaus von Burg Buchlau mit dem Wappen von Johann Filipec (mit Pfeil gekennzeichnet). Foto R. Vrla.

uherským panovníkem a českým králem.? Již v roce 1476 byl povýšen do šlechtického stavu a byl jmenován biskupem ve Velkém Varadínu (dnešní Oradea v Rumunsku), po smrti biskupa Tasa z Boskovic roku 1482 spravoval i olomouckou diecézi. V roce 1490 sehrál rozhodující roli při volbě Vladislava Jagellonského uherským králem, na biskupském místě se účastnil moravských zemských sněmů. Po korunovaci Vladislava Jagellonského $\mathrm{v}$ záŕí 1490 rezignoval na všechny své politické i církevní posty. Když vypořádal svůj majetek, vstoupil 10. června 1492 ve Vratislavi do františkánského kláštera. Sympatizantem tohoto řádu, který zřejmě poznal během jeho expanze v Uhrách, byl však již dříve. ${ }^{8}$ I v době, kdy se stáhl do ústraní, měl Filipec stále obrovskou autoritu a príležitostně jej

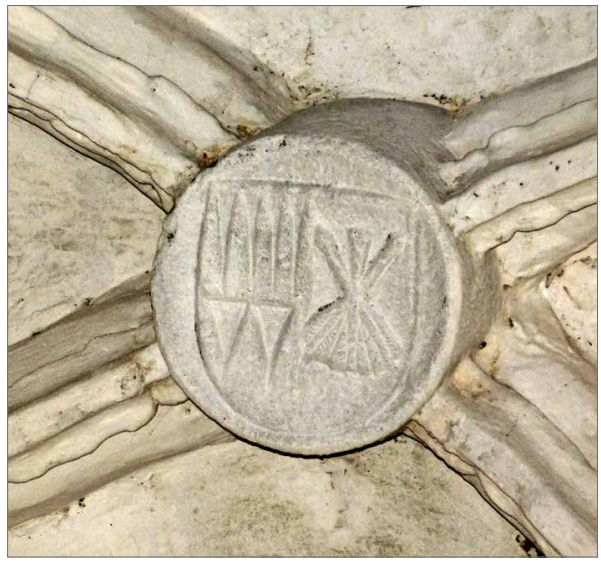

Obr. 20. Detail znaku Jana Filipce ze znakové galerie hradu Buchlov. Foto R. Vrla.

Abb. 20. Detail des Wappens von Johann Filipec aus der Wappengalerie von Burg Buchlau. Foto R. Vrla.

7 Aktivně působil jak ve střední Evropě (Uhrách, Rakousku, českých zemích, Slezsku), tak také ve Francii či Itálii. Účastnil se například poselstva, které mělo přivést Matyášovi novou manželku, dceru neapolského krále Ferdinanda I., Beatrix Aragonskou. Za svou činnost získal v Uhrách řadu církevních beneficií.

8 Zasloužil se o stavební a umělecký rozvoj františkánských klášterů a kostelů, např́iklad v Olomouci, další kláštery, jako v již zmíněném Uherském Hradišti, nebo slezském Jaworu, vlastním přičiněním založil. 
tak využíval i Vladislav Jagellonský. Také v rámci českých zemí udržoval kontakty s dřívějšími politickými partnery - známá je např́́klad jeho korespondence s Vilémem z Pernštejna či Petrem z Rožmberka. Svých cenných kontaktů využíval i ve prospěch františkánského řádu. $O$ úctě, které se Filipec těšil, svědčí také fakt, že místo jeho posledního odpočinku navštívil nedlouho po jeho smrti i panovník Vladislav Jagellonský.

Rodáka z Prostějova pojily s moravsko-slovenským pomezím, potažmo Uherským Hradištěm nejen františkánský klášter, jehož se stal zakladatelem a v jehož zdech spočinul, ale také osobní a rodinné vazby. Uherská Skalice s františkánským klášterem z roku 1467 se často stávala místem pobytu královského důvěrníka na jeho cestách z Budína na Moravu (Čoupek 2010, 6). Soukromé aktivity v pohraničním kraji pak napřímil k zajištění svého synovce Jana z Kunovic (syn Filipcovy sestry Zuzany a Duchka z Bydžova; Paprocký 1593; Pilňáček 2004, 120), jemuž zajistil výnosný statek zahrnující Kunovice a okolí. Jan na Filipcovy náklady studoval nejprve v Olomouci, pak od roku 1493 na univerzitě v Lipsku a posléze v Bologni (Hlobil 1991, 330). ${ }^{9}$ V první polovině 16. století se Jan z Kunovic stal jedním z předních příslušníků panského stavu na Moravě, nejvyšším komorníkem Markrabství moravského a současně jedním z ochránců nově založeného františkánského kláštera v Uherském Hradišti.

\section{Otázka objednatele kachlů}

Jedním z objednatelů kachlů s motivem velkovaradínského biskupa a olomouckého administrátora tak mohl být právě Filipcův dědic Jan z Kunovic, a to ne dříve než po roce 1496 (rok vymožení zletilosti pro Jana z Kunovic a předání majetku), spíše ale až po Filipcově smrti roku 1509.

Vedle lákavé hypotézy synovcovy vděčnosti vůči zámožnému strýci, která se projevila v reliéfu komorového kachle, se však naskýtá ještě jedna možnost. Místem, kam kachle mohly směřovat, mohl být i nedaleký hrad Buchlov. Ten byl roku 1484 předán z rozhodnutí zemského soudu jednomu z věřitelů, kterým byl zemský hejtman Ctibor Tovačovský z Cimburka (Janiš-Vrla a kolektiv 2018, 61). Ačkoli byl Buchlov královským zbožím v zástavě, věnoval mu zemský hejtman Ctibor Tovačovský z Cimburka velkou pozornost. Fakticky hrad považoval za součást rodové domény. $Z$ jeho doby se dochovala pozoruhodná znaková galerie na svornících $\mathrm{v}$ patře severozápadního paláce (Kasík 2000, 215-243). V rytířském sále se nachází sedm svorníků, na kterých se vedle centrálně umístěného erbu pánů z Cimburka nalézají erby dalších předních moravských panských rodů: ${ }^{10} \mathrm{z}$ Boskovic, Lomnice, Liechtensteina, Valdštejna, Pernštejna, Lipé, Lichtenburka ad. Tato část znakové galerie měla odrážet význam těchto rodů v dějinách a politickém zřízení Markrabství moravského. Pokračování buchlovské znakové galerie v tzv. zbrojnici, kde centrálně umístěný cimburský erb doprovázejí další dva znaky, lze považovat za symbolické vyjádření osobního vztahu ke spolupracovníkům a př́telům: Vilémovi z Pernštejna a Janu Filipcovi z Prostějova (obr. 19-20). Znaková galerie ještě pokračovala v tzv. malém rytířském sále aliančním znakem Ctibora Tovačovského a jeho manželky Elišky z Melic.

V souvislosti s budováním znakové galerie předních panských rodů na hradě se nabízí možnost, že pro tyto reprezentativní prostory mohlo vzniknout i otopné zařízení (otopná zařízení?) reflektující svým výtvarným pojetím zmíněné ambice. K němu by pak bylo možné vztáhnout i nálezy z Uherského Hradiště. Pro hypotézu otopného zařízení s heraldickými motivy předních panských rodů svědčí i další nálezy kachlů s poloválcovou komorou a s heraldickými motivy z Otakarovy ulice. Část z nich dosud není publikována a v různém stavu zachování zobrazuje heraldické motivy (torza erbů výše zmíněných šlechtických rodů, kolčí štíty, přikrývadla ad.)

\footnotetext{
9 V době nezletilosti Jana z Kunovic roku 1492 učinil Jan Filipec jeho poručníkem a správcem veškerých jeho statků pana Viléma z Pernštejna, svého důvěrného přítele a nejvyššího hofmistra Království českého. Roku 1496 se Vilém z Pernštejna po Filipcově výtce vzdal poručnictví a vymohl u krále uznání zletilosti Jana z Kunovic a majetek mu předal (Měštánek 2003, 125). Mezi statky Jana z Kunovic patřil i zámek a město Ostroh či původně královské město Uherský Brod, které Jan Filipec získal pro svého synovce roku 1506 za své zásluhy od krále Vladislava. Uherskobrodští měšt’ané se však cítili poníženi, že jejich město bylo vyňato z řad královských (Měštánek 2003, 115-117).

10 Za poskytnutí fotografií znakové galerie chci touto cestou poděkovat kastelánovi hradu Buchlov Ing. Rostislavu Joškovi. Autorem fotografií je Radim Vrla, jemuž touto cestou také děkuji za souhlas s publikováním.
} 
a je možné, že i publikovaný motiv pánů z Lomnice (Menoušková 2012) mohl být určen nikoli pro vzdálenější hrad Brumov, ale pro hypotetickou znakovou galerii blízkého hradu Buchlova. Takovéto otopné zařízení by nebylo v moravských podmínkách ojedinělé (srov. např. heraldické znaky předních panských rodů přibližně $\mathrm{z}$ téže doby $\mathrm{z}$ kachlů $\mathrm{z}$ hranického zámku; $\mathrm{k}$ tomu Miloš-Michna-Sedláčková 1998). Pokud bychom tuto hypotézu zasadili do časového rámce, měly by kachle odkazující k osobnosti Jana Filipce vzniknout před rokem 1494 (úmrtí Ctibora Tovačovského), méně pravděpodobně před rokem 1520 (kdy se hrad dostal do rukou Žerotínů od Arkleba z Boskovic; Janiš-Vrla a kolektiv 2018, 161-162).

\section{Závěr}

Reliéfně zdobené kachle patří bezesporu k atraktivnímu segmentu hmotné kultury, a to i přesto, že se často zachovají v neúplném či poškozeném stavu. Dva zde prezentované nekompletní exempláře s motivem biskupské mitry, berly a nápisové pásky s latinským textem ukazují na možnosti, ale i limity při interpretaci jejich ikonografie, ale i důležitých historických souvislostí. Jedná se o kusy získané během staršího předstihového výzkumu v Uherském Hradišti, Otakarově ulici. Místo nálezu je historicky i na základě archeologického výzkumu možné spojit s existencí a činností hrnčířských dílen. Minimálně jeden z fragmentů (lépe zachovaný kus z objektu 2) je možné s odpadem z hrnčířských pecí, a tedy i s uherskohradišt'skými hrnčíři dát do souvislosti. U menšího zlomku z odpadního objektu 7 bohužel stav zachování nedovoluje určit, zda zakouření patrné na zadní straně je výsledkem nepovedeného výpalu, a i tento kus byl tedy původně defektní a vyhozený ještě před použitím, nebo se jednalo o použitý kus z blíže neznámého otopného zařízení, které stávalo poblíž. Nemnoho zachycených exemplářù (v rámci jinak na kachle bohatých nálezových situací) však spíše naznačuje, že se jednalo o nepovedené zboží, nikoli o odpad $\mathrm{z}$ kamnového tělesa. $\mathrm{V}$ tom př́ípadě by počet kachlů (zlomků) $\mathrm{s}$ týmž motivem byl neporovnatelně větší.

Zachovaný reliéf kachlů - biskupská mitra, berla a patrně kolčí štít $\mathrm{s}$ motivem tří překřížených střel a latinský zkratkovitý nápis na nápisové pásce: $R$ in xpo $p d$ ep // wrd(e) ecl dei // „,g ioannes“, s hypotetickým čtením části „g.ioannes“, tedy: „Reverendus in Christo pater dominus episcopus Waradiensis ecclesiae Dei gratia /Ioannes etc./“ - odkazuje k postavě velkovaradínského biskupa, olomouckého administrátora a diplomata, významné osobnosti druhé poloviny 15. až přelomu 15. a 16. století Janu Filipcovi. Prostějovského rodáka, umírněného katolíka a představitele vesměs nábožensky tolerantního př́stupu (srov. Blahoslav 1458-1542) přivedly na sklonku jeho života rodinné i osobní vazby do oblasti moravsko-slovenského pomezí, kde se výrazně angažoval nejen při donaci františkánského kláštera v Uherském Hradišti, ale i při materiálním a finančním zajištěním svého synovce Jana z Kunovic. Ten také mohl na přelomu 15. a 16. století stát za objednávkou ikonograficky ojedinělého, výtvarně spíše strohého a řemeslně rutinně provedeného reliéfu (nejspíše místní provenience) nesoucího se již v renesančním duchu. Není však jediným možným objednavatelem. Přátelské pouto, které pojilo Jana Filipce s kališníkem Ctiborem Tovačovským z Cimburka, a Filipcův znak na svornících hradu Buchlov (v rámci znakové galerie významných šlechtických rodů a osob tehdejší doby) umožňují vyslovit hypotézu, že objednavatelem kachlů pro otopné zařízení mohl být i Ctibor Tovačovský z Cimburka, jenž hrad na konci 15. století držel v zástavě. Naopak žádné indicie prozatím nemáme $\mathrm{k}$ hypotéze, že by zadání motivu vzešlo $\mathrm{z}$ františkánského řadu či přímo od Filipce. Sám Filipec přes svůj vstup do řádu vedl stále ještě aktivní diplomatický život a byl často na cestách. Za finanční obnos, který uherskohradišt'ským františkánům poskytl, byly zakoupeny tř̌i městské domy se zahradami při židovském městě a posléze ještě mešní roucha, kalichy, knihy a další inventář. První mniši zřejmě bydleli ve vykoupených domech. O př́ípadných otopných zařízeních těchto domů nemáme zprávu. Nedochovala se ani relace o možné výměně původních kamen za nová, v nichž by kachle se znakem Jana Filipce byly použity. Jak dokládají prameny, byly hlavní stavební (a také finanční) aktivity napřímeny 
k výstavbě chrámu Panny Marie. ${ }^{11}$ Také z prostoru františkánského kláštera není dosud žádné otopné těleso pozdního středověku až časného novověku (či jeho pozůstatky) doloženo ani dle historických zpráv ani archeologicky. Přesto nelze (vzhledem ke stavu zachování fragmentu z objektu 7) vyloučit, že reliéf se znakem Jana Filipce mohl být použit (také?) na kamnech stojících přímo v Uherském Hradišti.

Výtvarně jednoduchý, ojediněle zpracovaný a historicky přínosný reliéf nemá adekvátní analogie v kachlovém materiálu. Řadu společných stylizačních prvků však lze najít mezi ním a kamenickými výtvory, které v rámci františkánského kláštera na Filipce odkazují (náhrobník, kamenicky zpracované znaky pod hlavní rímsou kostela i na východním křídle kláštera). Reliéf původně patrně výškového kachle s půlválcovou komorou se nese již v duchu renesančního tvarosloví. A ačkoli míra jeho řemeslného zpracování nijak nevybočuje $\mathrm{z}$ dobového průměru, historicky cenné téma, které zpracovává, výrazně hranici regionu přesahuje. Poukazuje navíc na další způsob ovlivnění moravského kachlového materiálu v době, kdy Morava připadla Matyáši Korvínovi. Nejedná se $\mathrm{v}$ tomto př́ípadě o př́mý vliv budínské královské dílny, který je v moravském materiálu již delší dobu znám a popsán (k tématu např. Michna 1974, 179-205; Cejnková-Loskotová 1994, 181-188; Jordánková-Loskotová 2002, 555-587; 2005, 445-456; Hložek-Jordánková-Loskotová 2018, 491-509), ale jde o jeden z projevů kulturních a hospodářských kontaktů mezi Moravou a Uhrami, které se v období Matyášovy vlády prohloubily. Že tyto vazby nabývaly nezř́idka také osobního charakteru, ukazuje i př́íklad uherskohradišstského kachlového reliéfu.

\section{Prameny a literatura}

BLAHOSLAV 1458-1542: Jan Blahoslav, Historia fratrum Bohemicarum inde ab anno 1458 usque anno 1542. Díl 1. Rkp. ulož v Národní knihovně, sign. FXVII 51a: Archiv český V.-XVII. (Palacký, F.-Kalousek, J., edd.). 1872-1900.

BRYCH, V., 2004: Kachle doby gotické, renesanční a raně barokní. Výběrový katalog Národní muzea v Praze. Praha.

BUBEN, M., 2003: Encyklopedie heraldiky. Světská a církevní titulatura a reálie. Praha.

CEJNKOVÁ, D.-LOSKOTOVÁ, I., 1994: Rytiřská kamna na Špilberku, Forum brunense 1994, 181-188.

ČOUPEK, J., 1984: Seznam ulic města Uherského Hradiště. Uherské Hradiště.

- 2010: Uherské Hradiště: Klášter františkánů a kostel Zvěstování Panny Marie. Velehrad.

FIŠER, B., 1921: Uherské Hradiště. Uherské Hradiště.

FOLTÝNOVÁ-MIKULCOVÁ, P., 1999: Jan Filipec, diplomat ze sklonku středověku, Dějiny a současnost $21,11-15$.

FROLÍK, J., 2003: Kachle Chrudimska. Sbírky regionálního muzea v Chrudimi 5/II. Chrudim.

FROLÍKOVÁ-KALISZOVÁ, D., 2002: Parohový hrací kotouček, Slovácko 44, 163-166.

- 2003: Olověný kř́ižek z Uherského Hradiště, Otakarovy ulice - Kleines bleiernes Kreuzchen aus Uherské Hradiště, Otakarova-Str., AH 28, 553-560.

- 2004: Zvírrecí kosti z 8.-10. století v Uherském Hradišti a jejich zpracování. Předběžná zpráva. In: Zborník na počest' Dariny Bialekovej (Fusek, G.. ed.), 75-80. Nitra.

- 2020: Archeologie o Uherském Hradišti v době velkomoravské: výzkumy, lidé, povodně (40 let od zahájení plošných výzkumů) - Die Archäologie über Uherské Hradiště zur Zeit Großmährens - Grabungen, Menschen, Überschwemmungen (40 Jahre seit Aufnahme großflächiger Grabungen), AH 45, 785-807. https://doi.org/10.5817/AH2020-2-13

GRUIA, A. M., 2013: Religious Representations on Stove Tiles from the Medieval Kingdom of Hungary. Cluj-Napoca.

11 Na základě zachovaných zpráv lze předpokládat, že v nejranějši fázi byl dokončen presbytář, obvodové zdivo lodi včetně hlavního vstupu portálu, klenuté předsíně a stupňovitého štítu. Zřejmě také došlo k zahájení výstavby kláštera. Šlo o jednokřídlou patrovou budovu vybíhající od presbytáře k severu. Takovou stavbu zachycuje Willenbergerův pohled na Uherské Hradiště ještě v roce 1593 (Čoupek 2010, 6-11). 
HAVLICE, J.-KYPTA, J. et al., 2017: Gotické kachle z Jindřichova Hradce. České Budějovice.

HLOBIL, I., 1991: Morava a uherská (italská) renesance za Matyáše Korvína. K 500. výročí první recepce renesance v českých zemích, ČMM CX, 325-338.

HLOŽEK, M.-JORDÁNKOVÁ, H.-LOSKOTOVÁ, I., 2018: The provenance of raw materials for the manufacture of a knight stove from Petrov, Brno, AH 43, 491-509. https://doi.org/10.5817/AH2018-2-10

JANIAK, T., 2003: Kafle gotyckie w zbiorach Muzeum Początków Państwa Polskiego w Gnieźnie. Gniezno. JANIŠ, D.-VRLA, R. a kolektiv, 2018: Hrady Zlínského kraje. Lukov.

JIŘÍK, J.-KYPTA, J., edd., 2013: Gotické kamnové kachle na Písecku. Výběrový katalog výstavy. Obrazový svět pozdního středověku. Písek.

JORDÁNKOVÁ, H.-LOSKOTOVÁ, I., 2002: Špilberská kachlová kamna a jejich stavebníci - Špilberker Kachelöfen und ihre Besteller, AH 27, 555-587.

- 2005: Kachlová kamna v prostorách minoritského kláštera v Brně - Die Kachelöfen in den Räumen des Minoritenklosters in Brno (Brünn), AH 30, 445-456.

KALHOUS, A., 2006: Jan Filipec v diplomatických službách Matyáše Korvína, ČMM CXXV, 3-32.

KASÍK, S., 2000: Znakové svorníky na hradě Buchlově, Slovácko 41 (1999), 215-243.

KVIETOK, M.-MÁCELOVÁ, M., 2013: Krása kachlíc. Katalog výstavy. Vzácne neskorogotické a renesančné kachlice. Bánska Bystrica.

MENOUŠKOVÁ, D., 2011: Městská heraldika na kachlích ze sbírky Slováckého muzea, Slovácko 52 (2010), 161-173.

- 2012: Znak pánů z Lomnice na reliéfech kachlů z Uherského Hradiště, Slovácko 53 (2011), 217-225.

- 2016: Dva raně novověké kachlové motivy z Uherského Hradiště, Slovácko 57 (2015), 151-159.

MENOUŠKOVÁ, D.-MĚŘÍNSKÝ, Z., edd., 2008: Krása, která hřeje. Výběrový katalog gotických a renesančních kachlů Moravy a Slezska. Uherské Hradiště.

MĚŠŤÁNEK, T., 2003: Biskup Filipec (1431-1509) a středoevropská politika. Uherské Hradiště.

MICHNA, P. J., 1974: Archäologische Nachweise der mährisch-ungarischen Beziehungen im 15. Jahrhundert, Folia archaeologica 25, 179-205.

MILOŠ, S.-MICHNA, P.-SEDLÁČKOVÁ, H., 1998: Pozdněgotické a renesanční kachle ze zámku v Hranicích. Olomouc - Hranice.

MORAVEC, Z., 2019: Kachlový soubor z Kostelního náměstí v Ostravě. Ostrava.

PAPROCKÝ 1593: Zrcadlo Slawneho Margkrabstwij Morawskeho: W kteremz geden kazdy Staw, dawnost, wzactnost y powinnost swau vhleda: sebrane ... Skrze Bartholomege Paprockeho z Glogol a Paprocke Woly Olomutii: Haeredes Milich-talleri, 1593. Rkp. Dostupné z: http://digital.onb.ac.at/OnbViewer/ viewer.faces?doc=ABO_\%2BZ169048003.

PAVLÍK, Č., 2017: Velký obrazový atlas gotických kachlových reliéfů. Čechy, Morava, české Slezsko. Praha.

PAVLÍK, Č.-VITANOVSKÝ, M., 2004: Encyklopedie kachlů v Čechách na Moravě a ve Slezsku. Praha.

PILŇÁČEK, J., 2004: Staromoravští rodové I. Velehrad.

POJSL, M., 2013: Olomoučtí biskupové a arcibiskupové a jejich pohřební místa. Uherské Hradiště.

PROCHÁZKA, R., 1979-1981: Terénní deník. Rukopis, ulož. v archivu archeologického oddělení Slováckého muzea.

SNÁŠIL, R., 1990-1991: Nálezová zpráva 739/01. Františkánský klášter, ulož. v archivu archeologického oddělení Slováckého muzea.

- 1991-1992: Zpráva o archeologických výzkumech a př́růstcích Slováckého muzea v roce 1991, Slovácko 33-34, 117-129.

STRAUSS, K., 1972: Die Kachelkunst des 15. und 16. Jahrhunderts in Deutschland, Österreich, der Schweiz und Skandinavien. II. Teil (neue Folge). Basel. 


\section{Zusammenfassung}

\section{Kacheln mit Bischofsmotiv aus Uherské Hradiště und ihr Bezug zu Johann Filipec ${ }^{12}$}

Die zwei hier vorgestellten nicht kompletten Blattkachelexemplare mit dem Motiv einer Bischofsmitra, eines Krummstabs und Inschriftbandes mit Text und Abbreviaturen in Minuskelschrift wurden in Uherské Hradiště bei einer älteren Vorlaufsgrabung in der Otakarova-Straße entdeckt. Der Fundort kann historisch und auch aufgrund der archäologischen Grabung auf die Existenz und Tätigkeit von Töpferwerkstätten bezogen werden. Mindestens eines der Fragmente (das besser erhaltene Exemplar aus Objekt 2) kann mit Töpferofenabfällen, also auch mit Töpfern aus Uherské Hradiště in Verbindung gebracht werden. Bei dem kleineren Fragment aus Abfallobjekt 7 erlaubt es der Erhaltungszustand nicht zu bestimmen, ob die auf der Rückseite erkennbare Verrauchung das Resultat eines misslungenen Brandes ist, oder ob es sich dabei um ein für eine nicht näher bekannte, in der Nähe betriebene Heizvorrichtung verwendetes Exemplar handelte. Obwohl es sich um keine ganzen Blattkachelexemplare handelt, kann ihr Relief relativ gut identifiziert werden. Eine Bischofsmitra, ein Krummstab und offenbar ein Tartschenschild mit dem Motiv von drei gekreuzten Pfeilen verweisen auf Johann Filipec, Bischof von Großwardein, Administrator von Olmütz und Diplomat und bedeutende Persönlichkeit der zweiten Hälfte des 15. bis zur Wende des 15. und 16. Jahrhunderts. Die Bestimmung wird auch durch die epigraphische Analyse des Textes gestützt. Die Inschrift beginnt am heraldisch rechten Rand der Grundfläche, wird im Uhrzeigersinn fortgesetzt und füllt das ganze Band: $R$ in xpo $p d$ ep // wrd (e) ecl dei // ,g ioannes “. Die Lesart „g.ioannes“ ist allerdings hypothetisch. Die Transkrition des Inschriftbandtextes lautet demnach: „Reverendus in Christo pater dominus episcopus Waradiensis ecclesiae Dei gratia I Ioannes etc. /“ In der Übersetzung dann: „Der ehrwürdige Vater in Christus Herr Bischof der Wardeinschen Kirche von Gottes Gnaden / Johann usw. /" Den aus Proßnitz stammenden gemäBigten Katholiken und Vertreter einer religiös durchweg toleranten Haltung führten familiäre und persönliche Gründe am Ende seines Lebens in das mährisch-slowakische Grenzgebiet, wo er sich nicht nur bei der Stiftung des Franziskanerklosters in Uherské Hradiště deutlich engagierte, sondern auch bei der materiellen und finanziellen Absicherung seines Neffen Johann von Kunowitz. Von diesem konnte an der Wende des 15. und 16. Jahrhunderts auch das ikonographisch einzigartige, künstlerisch jedoch eher grobe und handwerklich durchschnittlich ausgeführte Relief in Auftrag gegeben worden sein. Er ist jedoch nicht der einzige mögliche Auftraggeber. Die freundschaftlichen Bande, die Johann Filipec mit dem Kalixtiner Ctibor Tobischau von Cimburg verbanden, und das Wappen von Filipec im Rahmen der Wappengalerie bedeutender Adelsgeschlechter der damaligen Zeit auf den Schlusssteinen von Burg Buchlau ermöglichen auch die Hypothese aufzustellen, dass Ctibor Tobischau von Cimburg, von dem die Burg Ende des 15. Jahrhunderts als Pfand gehalten wurde, die Kacheln für eine Heizvorrichtung in Auftrag gegeben haben könnte. Es ist wenig wahrscheinlich, dass der primäre Impuls des Auftrags und der Vorgabe des Motivs vom Franziskanerorden oder direkt von Filipec ausging. Aus dem Raum des erst in der Entstehung begriffenen Franziskanerklosters ist weder in den schriftlichen Quellen noch archäologisch ein Heizkörper belegt. Das künstlerisch einzigartig bearbeitete und ganz an das Ende des 15. bis zum Beginn des 16. Jahrhunderts datierte Relief hat im Kachelmaterial keine entsprechende Analogie. Anführen lassen sich lediglich freie Analogien aus norddeutscher Umgebung (Strauss 1972, 132, Tafel 78, Nr. 3), aus Köln am Rhein (Strauss 1972, 148, Tafel 135, Nr. 2), aus Polen (Jankowo Dolne, bzw. ein Kachelfragment aus Gnesen; Janiak 2003,75, Katalog II.105; 78, Katalog II.121). Auch aus der weiteren Umgebung von Uherské Hradiště, die mit dem Schicksal von Johann Filipec direkt verbunden war, wurde kein adäquaterer Vergleich publiziert, sodass lediglich auf ein Fragment von Burg Varaždín verwiesen werden kann (heute

12 Der vorliegende Beitrag ist dem akademischen Bildhauer und führenden tschechischen Medailleur Michal Vitanovský, einem Experten auf dem Gebiet der Kachelheraldik und -technologie zu seinem Lebensjubiläum gewidmet. Ihm bin ich auch für seine inspirierenden Anregungen und Themen verpflichtet, mit denen er mich nicht nur beim Studium dieses Motivs bereicherte. Homo doctus in se semper divitias habet. 
auf dem Gebiet Kroatiens; Gruia 2013, 497, Kat. 418). Die Stilisierungen aller oben aufgeführten Reliefs erinnern jedoch nur weitläufig an das Exemplar von Uherské Hradiště, sodass wir eine direkte Analogie im Kachelmaterial vermissen. Eine Reihe gemeinsamer Stilisierungselemente lassen sich jedoch zwischen dem Relief aus Uherské Hradiště und den Steinmetzerzeugnissen finden, die im Rahmen des Franziskanerklosters auf Filipec verweisen (Grabstein, steinbildhauerisch bearbeitete Wappen im Untersims der Kirche und an der Ostseite des Klosters). Das Kachelmotiv aus Uherské Hradiště ist das Werk eines lokalen Schöpfers und im breiteren Wortsinn ein Spiegelbild der politischen und kulturellen Situation, durch deren Einfluss Mähren, Schlesien und die Ober- und Niederlausitz in den Jahren 1469-1490 unter die Herrschaft von Matthias Corvinus gelangten. Thematisch geht es jedoch deutlich über die Grenzen der Region hinaus. Das Relief der ursprünglich offenbar hohen Kachel mit einem halbzylindrigen Tubus ist bereits im Geiste der renaissancezeitlichen Formgebung getragen. Und obgleich der Grad ihrer handwerklichen Bearbeitung nicht vom Durchschnitt jener Zeit abweicht, geht das hier bearbeitete, historisch wertvolle Thema deutlich über die Grenzen der Region hinaus. Es weist darüberhinaus auf eine weitere Art und Weise hin, wie das mährische Kachelmaterial beeinflusst wurde. In vorliegendem Fall handelt es sich um keinen direkten Einfluss der Budaer königlichen Werkstätten, die im mährischen Material bereits seit längerer Zeit bekannt sind und beschrieben wurden (zu diesem Thema z.B. Michna 1974, 179-205; Cejnková-Loskotová 1994, 181-188; Jordánková-Loskotová 2002, 555-587; 2005, 445-456), sondern um eine der Erscheinungsformen der kulturellen und wirtschaftlichen Kontakte zwischen Mähren und Ungarn, die während der Herrschaftszeit von Matthias Corvinus vertieft wurden.

Mgr. Dana Menoušková, Slovácké muzeum v Uherském Hradišti, p. o., Smetanovy sady 179, 68601 Uherské Hradiště, Česká republika, dana.menouskova@slovakcemuzeum.cz 